\title{
FRANCISCO DE LA TORRE Y SU MUY PROBABLE PATRIA: SANTA FE DE BOGOTÁ*
}

En mi libro Los 1,001 años de la lengua española (1989), que es un intento de contar la historia de nuestra lengua a los legos - o, con eufemismo, a los lectores de "cultura general"-, dedico unos párrafos al carácter "imperial" de la literatura escrita en castellano durante los tres siglos de la Colonia. No había naciones, no había fronteras, no había pasaportes. Menciono a los escritores españoles que vivieron en el Nuevo Mundo durante un tiempo más o menos largo (como Cetina y Esquilache), algunos de los cuales escribieron aquí su obra (como Hernán González de Eslava y Juan de Castellanos). Menciono también a los escritores nacidos en el Nuevo Mundo que vivieron y escribieron en España (Garcilaso Inca, Ruiz de Alarcón). Y en la página 194 me atrevo a decir: "Es posible que Francisco de la Torre, uno de los buenos poetas de la época de Felipe II, haya sido natural de Bogotá". En vez de posible bien pude decir sumamente verosimil, pero esto me hubiera obligado a exponer

* A propósito de María Luisa Cerrón Puga, El poeta perdido: Aproximación a Francisco de la Torre, Pisa, 1984, y de Soledad Pérez-Abadín Barro, Los sonetos de Francisco de la Torre, Manchester, 1997. Además de Cerrón y Pérez-AbADín, emplearé estas abreviaturas:

Alatorre: Antonio Alatorre, "Garcilaso, Herrera, Prete Jacopín y don

Tomás Tamayo de Vargas”, apud Elias L. Rivers (ed.), La poesía de Garcilaso, Madrid, 1974.

Coster: Adolphe Coster, "Sur Francisco de la Torre", RHi, 65 (1925), 74133.

M. Pelayo: Marcelino Menéndez Pelayo, Bibliografía hispano-latina clásica, t. 6 (Horacio en España), Madrid, 1951.

Q. Prosa: Obras completas de don Francisco de Quevedo Villegas, ed. Luis Astrana Marín. Prosa, Madrid, 1941.

Q. Verso: id.: Verso, Madrid, 1943. 
razones, y el lugar no era el adecuado. Ahora lo digo ${ }^{1}-\mathrm{y}$, de paso, hago otro cambio: mejor que "uno de los buenos poetas de la época de Felipe II", Francisco de la Torre es uno de los tres "grandes" (con fray Luis de León y Francisco de Aldana) ${ }^{2}$.

De hecho, al decir posible no hice más que asentir a lo que hace muchísimos años dijo Bartolomé José Gallardo, gigante lector y crítico gigante. Al dar la noticia "bibliográfica" (Ensayo, t. 4, cols. 909-916) de la Milicia y descripción de las Indias (Madrid, 1599) del capitán Bernardo Vargas Machuca —una noticia de las buenas, de las detalladas y jugosas, en que Gallardo nos comunica no sólo lo mejor que contiene el libro, sino también sus comentarios y sus reflexiones-, da cuenta de los preliminares y copia el primer verso de las poesías laudatorias, y al llegar al soneto del "Licenciado Francisco de la Torre Escobar, natural de Santa Fe del Nuevo Reino de Granada", anota entre paréntesis: "Tal vez el verdadero autor de las poesías que algunos atribuyen a D. Francisco de Quevedo, su editor".

Gallardo hizo un llamado de atención a los historiadores y críticos de la literatura española (los "hispanistas" en general), "mas nunca fue su voz dellos oída", lo cual es raro, pues Gallardo no era un don nadie. Yo "traduzco" así su corazonada: "Es absurdo ver en Francisco de la Torre un heterónimo de

${ }^{1}$ Conste desde aquí: sostengo que el poeta Francisco de la Torre nació en Santa Fe de Bogotá, aunque carezco de pruebas "científicas" como las que nos podría dar, con suerte, una buena investigación en archivos bogotanos. Se trata de una hipótesis que expongo en forma de relato de hechos. Es el "método" que seguí al atribuir a Miguel de Barrios la "Fábula de Cristo y la Magdalena" en NRFH, 41 (1993), 401-458. Y lo que allí digo, p. 422, se aplica punto por punto al presente artículo: "No tengo pruebas documentales...; simplemente estoy convencido...; mis argumentos, que no son pocos, irán esparcidos..., cada uno en el lugar que le toque”. Pero si alguien llega a descubrir al "verdadero" Torre, o demuestra simplemente que lo que yo digo no puede ser, en ese mismo instante dejaré de sostener lo que sostengo.

2 Confieso que me asombré al ver que Robert JAmmes, un crítico admirable, califica de "mediocres" las poesías de Torre (en su ed. de las Soledades de Góngora, Madrid, 1994, p. 684). Pero inmediatamente me repuse de mi asombro. Sería tonto "demostrar" que Jammes se equivoca. No se equivoca: está diciendo lo que piensa. Si hubiera discusión, sería tan sin sentido como la de quién cuenta más en la historia de la música, si Schumann o Chopin. Lo único que digo es que me interesan las poesías de Torre. Son más imprecisas, más vagarosas que las de Góngora, y más cargadas del lado de los "afectos", pero están muy bien hechas; tienen una armazón lingüística impecable, y tienen también sentimiento. 
Quevedo. Lo que pasa es que nadie ha encontrado huellas de Torre en España. ¿No será porque era un bogotano que nunca residió en España y por lo tanto no dejó tras sí ningún rastro documental?". He hecho mía esa corazonada y la he llevado, creo, un poco más allá, aunque por caminos no precisamente "científicos". Desde hace mucho tengo a mi cargo en la Universidad Nacional un "Seminario de poesía de los siglos de oro" que comienza con Garcilaso y, tras un periplo de cinco o seis años, termina con Sor Juana Inés de la Cruz. El seminario consiste simplemente en hacer, sin prisas, una lectura detenida y a fondo (close reading) de una sucesión de poetas. Y cuando le llega el turno a Torre, a todos se nos impone su singularidad. ¿Qué poeta raro! Ese vocabulario tan fino, esa exquisitez en la hechura, esa intensidad lírica, esa ternura, esa melancolía... (Y lo sentimos todos, de manera que si no es un juicio "científico", objetivo, al menos es "intersubjetivo", lo cual cuenta.) Mi conclusión es: si Torre es avis rara, ello se deberá al hecho de que no pertenecía a la escena literaria de la península: era un solitario que, en la poco avanzada Bogotá de la segunda mitad del siglo Xvi, dio rienda suelta a sus muy personales sentimientos e imaginaciones.

Pero al mismo tiempo la poesía de Torre nos hace ver que, en su soledad bogotana, tuvo acceso a buenos alimentos espirituales. El comercio librero era muy activo. A los españoles y a los criollos de las Indias les llegaron en su momento - junto con libros de caballerías, tratados sesudos, ñoñerías devotas, etc.- - los poetas que se iban publicando en la metrópoli: primero Boscán/Garcilaso (1543), y luego el muy italianizante Cancionero de Esteban Gabriel de Nájera (1554), el Cancionero (1554) y la Diana (1559) de Montemayor, la Floresta de Ramírez Pagán (1562) y las obras de Lomas Cantoral (1578), de Herrera (1582) y de Pedro de Padilla $(1580,1587)$, además de las ediciones póstumas de Castillejo (1573), Gregorio Silvestre (1582), Aldana (1589) y Acuña $(1591)^{3}$. Y están, además, los libros italianos. No pocos de los sonetos de Francisco de la Torre son traducción/reelaboración de sonetos toscanos, o

${ }^{3}$ A fines del siglo xvi el novohispano González de Eslava, cuyo teatro es totalmente pre-lopesco, está ya familiarizado con el Romancero nuevo, la gran explosión de una nueva poesía. Cf. Margit Frenk, "Góngora, Lope, Liñán, en siglo XVI mexicano", Homenaje a Eugenio Asensio, Madrid, 1988, pp. 185-197. (No cuento los poemas heroicos, como el de Ercilla, ni las poesías devotas de un López de Úbeda.) 
sea que en el Nuevo Mundo corrían las mismas antologías (la de Dolce, la de Domenichi, la de Ruscelli) que circulaban en la península.

A esto hay que añadir los manuscritos poéticos elaborados a un lado y otro del Atlántico. En las Flores de baria poesía recopiladas en México en 1577 hay seis composiciones de Herrera (no editado hasta 1582), veinticuatro de Hurtado de Mendoza (no editado hasta 1610) y cinco atribuidas a Figueroa (no editado hasta 1625-26). (Entre las de Figueroa están las aplaudidas octavas "Sobre nevados riscos levantado...", que parecen ser de Pedro Laínez ${ }^{4}$.)

Pero merece especial consideración el movimiento contrario, el de los manuscritos poéticos llevados de las colonias a la metrópoli para que allí se imprimieran, porque en las colonias no había muchas imprentas, y sobre todo porque era ésa la única manera de que las obras tuvieran difusión ${ }^{5}$. Y esto vale lo mismo para los criollos que para los españoles residentes en Indias. Algunos de los manuscritos siguen escandalosamente inéditos, como la Silva de poesía de Eugenio de Salazar6. Otros estarán en espera de que alguien los descubra. Otros se habrán perdido. Pero otros tuvieron mejor suerte: en 1589 se imprimió la Primera parte de las Elegías de Juan de Castellanos, en 1591 el Petrarca traducido por Enrique Garcés, en 1599 El peregrino indiano de Antonio de Saavedra Guzmán, en 1602 la Miscelánea austral de Diego Dávalos y Figueroa, en 1604 el Parnaso antártico de Diego Mejía de Fernangil, en 1608 el Siglo de oro en las sel-

${ }^{4}$ Hay en las Flores unos treinta y cinco poetas más o menos bien identificados. Las composiciones que más abundan son las de dos poetas que vivieron algún tiempo en México: Cetina (más de 80) y Juan de la Cueva (32); les siguen Hurtado de Mendoza (24), el Licenciado Dueñas (17), Pedro de Guzmán (12) y Vadillo, amigo de Cetina (también 12). Hay asimismo algo de Baltasar del Alcázar.

${ }^{5}$ De no haber sido porque las obras de Sor Juana se imprimieron en España, la historia sería muy distinta. Los impresores mexicanos no le publicaron sino cosas breves (sobre todo villancicos).

${ }^{6}$ Es seguro que Salazar nunca pensó que pudiera imprimirse en México su Silva, y es natural que se la haya llevado a España y que se conserve en la B.N.M., donde están asimismo las Flores de baria poesía y el Cartapacio de Rosas de Oquendo, compilaciones a las cuales Pedro Lasarte, NRFH, 45 (1997), 45-66, añade una miscelánea mexicana que anduvo por España y fue comprada recientemente por la Universidad de Pennsylvania. En el ms. 19.661 de la B.N.M. hay cinco cosas del novohispano Terrazas, de cuyo prestigio tenía noticias Cervantes (La Galatea): cf. Alfonso Méndez PlanCARTE, Poetas novohispanos, t. 1, México, 1942, pp. xxiii-xxiv. 
vas de Erifile de Balbuena, en 1610 la Historia de la Nueva México de Gaspar de Villagrá, en 1611 la Cristíada de fray Diego de Hojeda, en 1624 el Bernardo de Balbuena, en 1666 el San Ignacio de Domínguez Camargo, en 1676 el Ramillete de Jacinto de Evia, en 1703 la Rítmica sacra de Álvarez de Velasco ${ }^{7}$. Las excepciones son pocas: el Arauco domado de Pedro de Oña (Lima, 1596), la Grandeza mexicana de Balbuena (México, 1604), la poesía y el teatro de González de Eslava (México, 1610) y Los sirgueros de la Virgen de Francisco Bramón (México, 1620).

Así, pues, el hecho de que el manuscrito de las obras poéticas de Torre haya ido a parar en España está muy dentro de la regla. (Según PALAu, Manual del librero, t. 28, p. [512], el impreso bogotano más antiguo que se conoce es de 1739.)

\section{El capitÁn VARGas Machuca y SU Libro AMERICANO}

Bernardo Vargas Machuca nació en Simancas en 1555; "a los quince años ciñó la espada y marchó a la guerra de Italia”, y hacia 1575 emprendió viaje a las Indias, donde permaneció más de veinte años ${ }^{8}$. Tuvo a su cargo la "pacificación" del recién creado reino de la Nueva Granada, o sea que llevó a cabo las operaciones militares y "diplomáticas" necesarias para tener bajo control las zonas de indios. Pero, como tantos otros militares del siglo xvI, era también afecto a las actividades del espíritu. Hacia 1596, cuando regresó a Madrid para pedir "mercedes", pudo aducir dos méritos: sus hazañas de "pacificador" y el libro que había escrito sobre cosas del Nuevo Mundo.

El "libro" consta en realidad de tres libros: un manual o vademécum del Conquistador (la Milicia indiana), una geografía de América (la Descripción de las Indias) y unas nociones elementales de cosmografía (Compendio de la Esfera) ${ }^{9}$. Los dos

${ }^{7}$ El cual emprendió viaje a la Madre Patria para tramitar la impresión. También Balbuena había llevado a España, en 1607, su Siglo de oro y su Bernardo. Todavía hacia 1670 el jesuita Francisco de Castro llevó a España su Octava maravilla, aunque en vano. (La 1aㅡ ed. es de México, 1729.)

8 Aprovecho las anónimas "Noticias" que preceden a la Milicia indiana en su reedición de Madrid, 1892 (Colección de libros raros o curiosos que tratan de América, ts. 8 y 9).

9 "Todos estos libros están respirando la consumada ciencia y prudencia del autor", dice GALLARDo (y añade que se vio "precisado a no dejar la pluma de la mano para apuntar tantas y tantas especies peregrinas como encierran"). 
primeros se escribieron en Bogotá a lo largo de los años ("mucho tiempo", dice el privilegio, de octubre de 1598), y el tercero, que es muy breve, se escribió en Madrid "en tanta calamidad de tres años de pretensiones como yo he tenido" (Prólogo $)^{10}$. Mañosamente, en la dedicatoria al presidente del Consejo de Indias da a entender Vargas Machuca que, en vez de estarse mano sobre mano durante tres años (como tantísimos pretendientes), él ha compuesto la Milicia y la Descripción "en ratos desocupados de mis pretensiones (del premio de mis servicios)..., tomando por blanco el real servicio, en el entretanto que se me manda volver a tomar las armas" para seguir sirviendo a la Corona. Pero esos "ratos desocupados" pertenecen al Nuevo Mundo, no a Madrid. Las actividades de "pacificador" no parecen haber sido de tiempo completo. En la Milicia cita el autor constantemente, como ejemplo para conquistadores modernos, las ilustres hazañas de Alejandro y de Julio César, señas de que gozó del ocio necesario para leer la Historia de Quinto Curcio y los Comentarios de César (seguramente en traducción) ${ }^{11}$. Además, aunque el núcleo de la Milicia y de la Descripción es su experiencia personal, todo el tiempo está mostrando el fruto de las conversaciones que ha tenido con otros expertos, aunque también suele "extrapolar" a todo el Nuevo Mundo su experiencia neogranadina ${ }^{12}$. Y, finalmente, por lo menos dos de las poesías laudatorias muestran que Vargas Machuca estuvo en contacto con gente de letras de la Nueva Granada.

10 En la ed. de 1892, el Compendio de la Esfera ocupa apenas once páginas. Lo "compendiado" es la famosa Sphaera de Sacrobosco, que vino a ser la exposición vulgata de la doctrina geocéntrica de Ptolomeo (la única admisible en el orbe hispano-católico). Ciertamente el Compendio no necesitó tres años para ser escrito, pero Vargas Machuca tuvo que inflar sus méritos para que le hicieran caso. Los conocimientos cosmográficos son útil complemento de los geográficos; y el autor, que evidentemente leyó la Sphaera durante sus antesalas en el Consejo de Indias, está muy ufano de estos conocimientos recién adquiridos: el retrato que se mandó hacer en 1598 (grabado impreso al final de los preliminares) lo muestra como soldado y cosmógrafo; su lema es "A la espada y el compás/ más y más y más y más".

11 En cambio, no parece haber leído a Las Casas, ni a Oviedo, ni a López de Gómara. A quien cita una vez, a propósito de la piedra bezar, es a Nicolás Monardes.

$12 \mathrm{Su}$ presencia en la Nueva Granada parece haber sido precedida por una estancia en las Antillas. En todo caso, en 1578 (t. 2, p. 118) se encontraba en Santiago de Cuba. 
De hecho, el conjunto de las poesías preliminares nos hace ver que Vargas Machuca fue amigo de militares y de letrados. De los diez elogiadores, cuatro llevan el título de "capitán" y otros tantos el de "licenciado". La presencia de Pedro Liñán de la Riaza, del futuro segundo conde de Villamediana y de Luis Tribaldos de Toledo muestra que, al volver a la patria, Vargas Machuca siguió cultivando una afición adquirida en la Nueva Granada, que fue donde trató a hombres de letras, fuesen españoles o criollos ${ }^{13}$. En el manuscrito que llevó a Madrid había ya por lo menos dos composiciones de alabanza debidas a poetas neogranadinos ${ }^{14}$. Digo "por lo menos" porque bien puede ser que algunos de los capitanes y licenciados poetas hayan sido españoles residentes en la Nueva Granada, de manera que sus nombres - Luis Bravo de Acuña, Lázaro Luis Iranzo, Hernando de Mena, Cipriano de la Cueva Montesdoca y Gonzalo Mateo de Berrio - serían tan desconocidos para el lector español como los del capitán Alonso de Carvajal y el licenciado Francisco de la Torre Escobar ${ }^{15}$. Carvajal, "natural de la ciudad de Tunja", es autor de la primera de las diez poesías, "Epístola persuasoria al sabio y prudente lector" (especie de prólogo versificado), y Francisco de la Torre, "natural de Santa Fe del Nuevo Reino de Granada", es autor de uno de los sonetos.

Gallardo, que observa el gran número de poesías laudatorias, hubiera podido agregar que también es grande el número de aprobaciones: hay primero una sin fecha, en seguida otras dos, de 1597 (octubre y diciembre), y luego una más —la defi-

13 Dice Vargas Machuca: "Todos los criollos de todos tres reinos [la Nueva España, la Nueva Granada y el Perú] tienen gallardos entendimientos y son grandes hombres de a caballo, y si los empleasen para que ejercitasen las letras y las armas, serían señalados varones" (t. 2, pp. 194-195). Esta opinión se parece mucho a la que el doctor Juan de Cárdenas tenía (1591) sobre los criollos de México. Cf. A. Alatorre, "Historia de la palabra gachupin”, Scripta philologica in honorem Juan M. Lope Blanch, México, 1992, pp. 288-290.

14 Antonio Gómez Restrepo, Historia de la literatura colombiana, Bogotá, s. a., pp. 74-76, copia escuetamente ("no obstante su ningún valor poético") estas dos composiciones.

15 Dice Gallardo: "Pocos libros ofrecerán más [poesías laudatorias] ni de más aventajados ingenios: Vargas se conoce que estaba bien relacionado". Pero exagera en cuanto a los quilates de los "ingenios". De hecho, sólo dos de los alabadores, Pedro Liñán de la Riaza y Luis Tribaldos de Toledo, tenían cierto renombre literario. El futuro Villamediana era en 1598 un mozalbete de quince años, pupilo de Tribaldos. 
nitiva, la que por fin hizo que se le concediera al autor el ansiado y necesario "privilegio"- de 8 de agosto de 1598. O sea que la larga espera (de "tres años") queda bien explicada16.

He aquí el soneto de Francisco de la Torre:

El español que halló la nueva tierra tras larga mar, tras larga desventura, gozó del oro que la tierra dura en sus entrañas escondida encierra;

y, si del vulgo la opinión no yerra, ensalzando de Cristo la fe pura venció tras el despojo que asegura la más dudosa y más difícil guerra.

Vos solo, a quien tocó la mejor parte deste triunfo inmortal, muestra habéis hecho que fue vuestro despojo este tesoro: aquí nos dais del conquistar el arte, virtud que en un hidalgo honrado pecho se estima mucho más que plata y oro.

$\mathrm{Al}$ igual que los otros ocho sonetos, el de Francisco de la Torre elogia exclusivamente "el arte del conquistar", o sea la Milicia indiana ${ }^{17}$, que es lo más sobresaliente de la obra de Vargas Machuca. Es justo - dice- que las fatigas del conquistador sean recompensadas con honores y riqueza, sobre todo cuando ese conquistador ha escrito un libro que es condensación de una larga experiencia ${ }^{18}$. Claro, quien habla aquí no es el Torre que conocemos, sino un Torre "sociable", en relación

16 Evidentemente, las dilaciones se debieron a la resistencia de las autoridades: un libro sobre cómo mantener subyugados a los indios podía dar nuevas armas a los "enemigos de España", y más en esos momentos en que se estaba consolidando la "leyenda negra". Por algo Felipe II el "Prudente" prohibió la publicación de los escritos de fray Bernardino de Sahagún y mandó suspender la impresión de la Historia de Fernández de Oviedo.

17 Alonso de Carvajal es el único que elogia por parejo la Milicia (“...rindiendo a fuerza al indio indomitable,/ que Julio César no tuvo más arte”) y la Descripción de las Indias (“...cual Ptolomeo da de Indias alturas,/ derrotas de mar, tierras con distancia").

18 Las mencionadas "Noticias" anónimas no dicen si Vargas Machuca recibió en efecto algunas mercedes. Lo que dicen es que el pretendiente se quedó en Madrid, donde publicó (en 1600, 1619 y 1621) tres tratados sobre la gineta, o sea el arte de montar a caballo. (El segundo, Teórica y exercicios de la gineta, lleva al comienzo una Epístola del ahora ya conde de Villamediana, según el cual Vargas Machuca "ha servido a Su Magestad de 
con el prójimo. Pero su soneto ocupa un lugar digno entre los otros, y tiene versos - como "tras larga mar, tras larga desventura"- que no desdicen de la "manera" de Torre.

Francisco de LA TORRE PRESENTAdo POR Quevedo

A fines de 1631 salieron a la luz las Obras de Francisco de la Torre gracias a don Francisco de Quevedo, el cual, en su dedicatoria a Ramiro Felipe de Guzmán, dice haber hallado el manuscrito en casa de un librero, seguramente de Madrid, que se lo vendió "con desprecio" (por unos pocos maravedíes). Las Obras estaban ya "rubricadas del Consejo para la imprenta", o sea con el imprimatur oficial, y su aprobación estaba firmada por don Alonso de Ercilla; pero, por alguna razón, la impresión no se llevó a efecto. El nombre del poeta estaba borrado "en cinco partes" del manuscrito, pero pudo ver Quevedo que se llamaba Francisco de la Torre.

¿Quién sería ese desconocido? De no haber sido por el conde de Añover, Quevedo se habría quedado en ayunas. La respuesta a esa pregunta - le dijo Añover- está en la Octava rima de Juan Boscán, allí donde evoca a poetas de tiempos pasados y, después de Juan de Mena y antes de Garcisánchez de Badajoz, pone "al Bachiller que llaman de la Torre", elogiándolo por "la fuerça de su estilo"19. Se trataba, pues, de un poeta antiquísimo. El comentario de Quevedo - “[A esta] antigüedad... se pone duda el propio razonar suyo tan bien pulido"- no es una confesión de escepticismo, sino una ponderación enfática del lenguaje del poeta, "tan pulido" pese a tamaña antigüedad.

Naturalmente, todo esto es tramposo. Quevedo tenía que ver, por ejemplo, que Torre traduce o imita de cerca a Guidic-

cincuenta años a esta parte”.) También escribió Vargas Machuca una Defensa de la conquista de las Indias que no llegó a publicarse, quizá por las mismas razones que detuvieron durante tres años el permiso para imprimir la Milicia. (La solemne defensa oficial de la conquista, o sea el De justa Indiarum Occidentalium inquisitione, acquisitione et retentione de Solórzano Pereira, se publicaría en 1629.)

19 Obras poéticas de Juan Boscán, eds. Martí de Riquer et al., Barcelona, 1957 , p. 383. Quevedo no dice "fuerça de su estilo", sino que lo cambia en "grandeza de su estilo". Quizá lo hace adrede, para darle a Torre la grandeza que Rioja había atribuido a Herrera: cf. infra, nota 46. 
cione, a Varchi, a Amalteo y a Torquato Tasso, poetas del siglo XVI. Por eso lo que dice de la "antigüedad" de Torre es tan exquisitamente ambiguo: él sabe que Torre escribió en la segunda mitad del siglo xvi, pero se las arregla para que el lector quede persuadido de que fue contemporáneo de Garcisánchez, o sea muy anterior a Boscán y Garcilaso, y se quede pasmado ante tan increíble "pulimiento": ese "corriente de los versos" (o sea fluidez), esa "blandura", esa "facilidad" y, para colmo, esa lengua "no achacosa con vozes ancianas", "se puede[n] contar por milagro del ingenio" 20 .

Los aprobantes de las Obras, Lorenzo Vander Hammen y José de Valdivielso, no dicen nada en cuanto a la antigüedad de Torre. Los únicos contemporáneos de Quevedo que tocan el punto son Lope de Vega y Manuel de Faría y Sousa (cf. CERRÓN, pp. 17-19). El testimonio de Lope es curioso porque se escribió en 1630, cuando las Obras de Torre no se habían impreso aún (Quevedo debe de habérselas mostrado). Es obvio que Lope no veía en Torre a un contemporáneo de Garcisánchez, pero atenúa su opinión como Dios le da a entender, y dice -mentirosamente- que " $[\mathrm{e}] 1$ divino Francisco de la Torre" fue "celebrado del mismo Garcilaso [!],/ a cuyo lado dignamente corre". En cambio Faría y Sousa, sin compromisos con nadie, dice con toda claridad (en 1639) que Torre es posterior a Garcilaso, reconociendo, eso sí, que "compite con él”.

La edición quevediana no parece haber tenido mucha demanda, y pronto quedó sumida en el olvido. Lo cual es natu-

${ }^{20}$ La fingida sorpresa de Quevedo se parece a la sorpresa real de Gonzalo Argote de Molina (Discurso sobre la poesía castellana, ed. L. F. Tiscornia, Madrid, 1926, pp. 39-40) al toparse, en 1575, con estos endecasílabos en los Enxiemplos de don Juan Manuel: "Non aventures muncho tu riqueza/ por consejo del home que ha pobreza”. El descubrimiento de la gran antigüedad del endecasílabo, al igual que el hallazgo de versos como los de Torre, rebajaba la fama de prioridad de Boscán y Garcilaso. "Al cabo de algunos siglos que andava desterrado de su naturaleza" (esto es, de su patria), el noble endecasílabo, dice Argote, "ha buelto a España, donde ha sido rescebido y tractado como natural". Pero él también hace algo de trampa: da a entender que el endecasílabo, de tan usado en la España medieval, cayó en desuso y entonces lo acogieron Dante y Petrarca. (¡Con razón el endecasílabo es, en nuestra lengua, "más liso y sonoro que alguna vez paresce en la ytaliana"!). Quevedo hubiera podido decir que las formas poéticas de Garcilaso (sonetos, canciones, liras, églogas, etc.) están ya en Francisco de la Torre; pero, estratégicamente, se abstuvo de llevar su "tesis" hasta consecuencias tan extremas. 
ral: la poesía española andaba en 1631 por muy otros caminos. La fama de Torre no data de entonces, sino de 1753, cuando Luis José Velázquez reeditó por fin las Obras. Ante la falta de testimonios sobre Torre, Velázquez concluyó que se trataba de una máscara tras la cual se ocultaba el propio Quevedo. (Francisco de la Torre venía a ser así tan "heterónimo" suyo como Ricardo Reis lo es de Fernando Pessoa.) López de Sedano (Parnaso, t. 1, 1768) aceptó sin más lo dicho por Velázquez. Pedro Estala, que hilaba más delgado, hizo ver (1786) que Torre pertenecía a la época de Felipe II, y lo mismo dijeron Moratín (1788) y Quintana (1807). Sin embargo, todavía George Ticknor (1849) aceptaba la ecuación Torre = Quevedo (cf. CERRÓN, p. 22), la cual, a juzgar por el comentario que cité al principio, seguía siendo moneda corriente aun en tiempos de Gallardo ${ }^{21}$.

En 1925 era ya tal el número de Franciscos de la Torre localizados en toda clase de documentos, que el hispanista norteamericano J. P. Wickersham-Crawford pudo escribir: "Si Francisco de la Torre hubo de sufrir mucho por la crueldad de su amada Filis, aún más ha tenido que sufrir después de su muerte a manos de los que han tratado de recoger las noticias de su vida" 22 . Pero esta humorada no arredró a los detectives. En su libro Entre fray Luis y Quevedo (1982), "verdadero monumento de documentación", Antonio Blanco hace una lista de "cuarenta y tres Francisco[s] de la Torre", cuarenta y tres "aspirantes" a ocupar el vacío ${ }^{23}$.

En verdad, la investigación ha quedado hundida en el Quod nihil scitur. Torre — dice CERRón, p. 33- "era ya una incógnita

21 Aureliano Fernández-Guerra y Orbe dedicó su discurso de ingreso en la Academia de la Historia (1857) a probar que Torre y Quevedo fueron personas distintas. Su presentación del Francisco de la Torre "real" está hecha de puros fantaseos (aplaudidos por Menéndez Pelayo), pero al menos dejó asentado que Torre existió.

22 Citado por Cerrón, nota 50. Una cuarta parte de este libro (pp. 2347 ) se dedica a resumir la historia de lo que se ha especulado sobre quién fue Torre desde que la identificación con Quevedo fue abandonada. De allí proceden los datos de este párrafo.

23 Blanco mismo se decide por uno de los 43, jesuita de familia de conversos que vivió de 1521 a 1582. Hay un par de candidatos salmantinos, pero no llamados Francisco de la Torre: para Jorge de Sena (Francisco de la Torre e D. João de Almeida, 1974), Torre es el salmantino Miguel Termón; Coster, pp. 87-92, dice que durante un tiempo estuvo tentado a ver en Francisco de la Torre un pseudónimo de Fernando de Herrera (pero que luego abandonó esa idea). 
al poco tiempo de su muerte". Pero como no sabemos cuándo murió, sería mejor decir que fue siempre una incógnita. El señor Alonso Zamora Vicente (en su ed. de Torre, Clás. cast., 1944, p. xxi) llega al franco pirronismo: no sólo no sabemos nada sobre el poeta, sino que ignoramos "si existió siquiera, y quizá no pueda conocerse nunca”. Soledad Pérez-Abadín, más cauta o más sensata, dice sólo (p. 15) que "el problema de la identidad... no ha alcanzado una solución concluyente". En todo caso, Torre no es ya un ente fantasmal. El hallazgo de un manuscrito de las Endechas ${ }^{24}$ le arranca a Cerrón un como suspiro de alivio: ¡ese manuscrito "nos certifica que Francisco de la Torre existió"! 25.

\section{TORRE Y SUS CONTEMPORÁNEOS}

He dicho que a todo lector de Torre se le impone su singularidad, su extraordinaria concentración en ciertos temas y en ciertos sentimientos y en cierto lenguaje. Pero si ese lector lo es también de otros poetas de tiempos de Felipe II, constantemente estará viendo que Torre no es sino uno de ellos. Todos caminan

${ }^{24}$ Vale la pena reflexionar sobre este hallazgo. Las Endechas, que constituyen el libro III de las Obras, están en un manuscrito de la B.N.M. que perteneció a don Agustín Durán, el cual incluyó en su famoso Romancero una de las endechas (la segunda), que era la única aprovechable, por ser asonantada. Estas Endechas eran parte de un manuscrito más amplio, del cual fueron arrancadas. En ellas, dice CERRón, p. 50, hay "grafías a todas luces más arcaicas" que las de la edición quevediana, lo cual es normal: entre los últimos decenios del siglo XVI y primeros del XVII las imprentas del reino uniformaban la ortografía (no existían "ediciones paleográficas"). El manuscrito de donde se arrancaron las Endechas contendría, naturalmente, todas las Obras, y todas tendrían esas grafías que resultaban arcaicas frente a las usadas en 1631. No es imposible que fuera el autógrafo, pero es más verosímil que se trate de una copia poco posterior a él. El autógrafo sería lo que compró Quevedo. Y hay un hecho interesante: el nombre del poeta en ese ms. de las Endechas es "Francisco de la Torre", sin el "bachiller" que tramposamente le encajó Quevedo.

${ }^{25}$ Dice también (p. 43): "Al ser las poesías de Francisco de la Torre traducciones e imitaciones de las de los italianos, deducimos una de las pocas certezas que sobre la vida de nuestro poeta poseemos: o bien estuvo en Italia, o bien se relacionó estrechamente con personas que por aquí anduvieron". Sí, pienso yo: a lo mejor Bernardo Vargas Machuca, que anduvo por Italia en su adolescencia, se aficionó allí a la poesía y años después, en Bogotá, le reveló a su amigo Torre ese tesoro. Pero es hipótesis inútil: las antologías de poetas toscanos corrían en todas partes, y ningún poeta de habla española tomaba clases de italiano para entenderlos. 
por el sendero que Garcilaso trazó a la poesía española, todos se nutren de Petrarca y de modernos como Benedetto Varchi. A propósito de la antología que seguramente tuvo Torre en las manos, dice Cerrón, p. 32, que "precisamente son las traducciones las que marcan la pauta de lo que luego será su poesía original”. Lo cual vale para Torre lo mismo que para sus coetáneos. Garcilaso, por lo demás, ya había asimilado mucho de la poesía italiana (y latina). No es invención suya el canto amebeo con que termina la Égloga III, pero cuando Torre compone cantos amebeos en dos églogas del libro IV, su modelo inmediato y obvio no es Sannazaro, sino Garcilaso. Así en la primera:

Tirreno

El álamo de Alcides escogido...

Alcino

El fresno por la selva en hermosura...
Títiro

El mirto a Venus y el laurel a Febo...

Palemón

De Cibeles el pino fue preciado...,

y así también en la octava:

Tirreno

Flérida para mí dulce y sabrosa... Lícida mía, más que el cielo hermosa...

\section{Ergasto}

Hermosa Fili, siempre yo te sea... $\quad$ Fílida mía, más resplandeciente...

El homenaje de Torre a Garcilaso es especialmente vistoso en la oda 1 del libro I, cuasi-paráfrasis del célebre soneto "En tanto que de rosa y azucena...":

...Agora que el Oriente

de tu belleza reverbera, agora

que el rayo transparente

de la rosada Aurora

abre tus ojos y tu frente dora, antes que la dorada

cumbre de relucientes llamas de oro,

húmida y argentada

quede inútil tesoro 
consagrado al errante y fijo coro, goza, Filis del aura

Vendrá la temerosa

noche, de nieblas y de vientos llena;

marchitará la rosa

purpúrea, y la azucena

nevada, mustia tornará de amena.

Para comprobar lo "no singular" de Torre, lo que tiene en común con los poetas de su generación ${ }^{26}$, lo mejor será ver, in nuce, algunas muestras concretas del parentesco:

1) Apóstrofe a Venus:

a) Madre de Amor gentil, que cuando el día...

b) Alma Venus gentil, que al tierno Arquero...

c) Santa madre de Amor, que el yerto suelo...

2) Apóstrofe al Sol:

a) Rojo Sol, que con hacha luminosa...

b) Claro y sagrado Sol, que con la viva...

3) Apóstrofe a la Noche:

a) Santa y amiga Noche, que en tu olvido...

b) Noche, que en tu amoroso y dulce olvido...

4) Sonetos "optativos":

a) Así las ninfas del Sebeto ameno...

de flores te coronen...,

que escuches, nueva Aurora, el nuevo intento de mi zampoña...

b) Salve, sagrado y cristalino río...: así tus ninfas te detengan..., que saques la cabeza, serenando este cerco de nubes...

26 Dije antes "poetas de tiempos de Felipe II", cosa no muy precisa, puesto que durante no pocos años de esa época estaban ya muy activos Lope y Góngora. Sería mejor decir “poetas activos hacia 1565-1580”, poetas muy innovadores en relación con Cetina y Acuña, pero ya "superados" en 1605, pues Espinosa no los incluye en sus Flores. 
5) Remate de los sonetos:

a) ...fueron de mi prisión la red y anzuelo, y son, Filis, en vos milagro raro.

b) ...armas fueron del crudo Amor tirano, y agora son trofeos de mi triunfo.

c) ...mas ¿quién podrá excusarme lo que paso, sabiendo que ha de ser en vuestra ausencia?

d) ...y en medio del llorar sólo esto suena: “¿Cuándo volveré, Nise, a ver tus ojos?”

e) ...¿¿quién podrá remediar mi perdimiento, si faltan del amor las esperanzas?

๑) Los ojos de la amada:

a) ...salir siento, claros ojos süaves, a porfía unos rayos...

b) el rayo que salió de vuestros ojos...

c) y con los encendidos rayos rojos que por los ojos en el alma encierra...

7) La hermosura de la amada:

a) Filis, el sol, el alabastro y grana, el ébano, el coral, marfil y oro...

b) El ébano, el marfil, la nieve pura y las delgadas hebras de oro fino...

c) El oro crespo al aura desparcido...

d) el ébano, marfil, nieve, ostro, oro, la púrpura, coral, jacinto y rosa...

Si a un amante "normal" de poesía española se le dieran a leer los sonetos de donde proceden mis citas, ocultándole el nombre de los autores, le sería imposible descubrirlo. Son versos de seis poetas distintos: Aldana, Pedro Laínez, Lomas Cantoral, Herrera, fray Luis de León y Francisco de la Torre ${ }^{27}$. Seis

27 Los autores de los versos que cito son: 1) Lomas Cantoral, Aldana, Torre; 2) Herrera, Torre; 3) Lomas Cantoral, Torre; 4) Aldana, Torre; 5) Lomas Cantoral, Torre, Lomas Cantoral, fray Luis de León, Torre; G) Lomas Cantoral, Herrera, Torre; y 7) Lomas Cantoral, Pedro Laínez, fray Luis, Torre. Mis citas proceden de distintos lugares del libro de Pérez-AвADín (fruto de mucha lectura y mucha paciencia) en que se documentan las afinidades de Torre con sus contemporáneos. Si las apretadas notas de pie 
poetas que hablan la misma lengua, imitando sonetos italianos; seis poetas igualmente sensibles a las exquisiteces del Cinquecento italiano, igualmente entregados a la gozosa tarea de crear un nuevo lenguaje poético, un lenguaje "manierista" que, desde nuestra perspectiva, está a caballo entre el lenguaje "clásico" de Garcilaso y sus epígonos y el lenguaje "barroco" de Góngora y sus secuaces. Y es significativo que entre esos seis se encuentre el muy sevillano Herrera al lado del muy salmantino fray Luis ${ }^{28}$. Los dos poetas más afines a Torre, como claramente lo muestran los delicadísimos análisis de Pérez-Abadín, son Herrera y Lomas Cantoral (afinidad parecida a la que había habido entre el castellano Acuña y el andaluz Cetina).

El primero que vio "el interesantísimo problema de las semejanzas entre la poesía de [Torre] y la de Herrera" (palabras de Cerrón, p. 77) fue Quevedo en el prólogo de las Obras. Lo vio, y acto seguido le dio una solución contundente. Como el "bachiller" Francisco de la Torre es muchísimos años anterior a Herrera, ni duda cabe de que Herrera plagió a Torre, y lo plagió sistemáticamente. Lo dice varias veces en el prólogo, pero de manera muy comedida, y cada vez que estampa el nombre de Herrera le acomoda un floripondio: "doctíssimo y elegantíssimo escritor", "divino ingenio", "cuidadosa lima”, "grave y erudito maestro", que con "docto juyzio" tomó a Torre "por maestro y exemplo, imitando su dicción y tomando sus frasis" hasta identificarse prácticamente con él, de manera que resulta tan loable por haber adoptado ese lenguaje como Torre por "averlo enseñado primero".

¿Qué enorme diferencia entre estas palabras y el destemplado tono de las que unas paginitas atrás ha estampado Quevedo! Le dedica al joven yerno de Olivares — dice- "las Obras

de página, sobre todo las del capítulo 3 (los temas) y las del 5 (la estructura) pasaran al texto con las ampliaciones necesarias, su libro bien podría llamarse Los sonetos de la generación 1565-1580 en vez de Los sonetos de Francisco de la Torre.

${ }_{28}$ No suelen tomarse muy en cuenta los sonetos manieristas de fray Luis. Es verdad que son sólo cinco, pero esto mismo nos hace ver cómo, al apartarse de Horacio o de la poesía bíblica para prestar oídos a los acentos del petrarquismo, fray Luis adoptó, se diría que forzosamente, el lenguaje de sus tiempos. El soneto "Amor casi de un vuelo me ha encumbrado..." se inspira en el muy traducido de Tansillo, "Amor m'impenna l'ale, e tanto in alto..."; los sonetos "Alargo enfermo el paso y vuelvo, cuanto..." y "Agora con la Aurora se levanta..." parecen totalmente de Herrera. 
de Francisco de la Torre, que por tantos años ha ocultado con malicia algún ingenio mendigo, de los que, siendo hipócritas de estudios, piden a la invidia y al trabajo ageno lo que la naturaleza y la arte negaron al suyo". No menciona a Herrera por su nombre, pero no puede tratarse sino de él ${ }^{29}$. Según el prólogo, Herrera tuvo el gran acierto de arrimarse a los buenos; según la dedicatoria, Herrera, pobre diablo, ingenio lego, sin pizca de talento, tuvo secuestrado todo el tiempo el manuscrito de Torre (único, según eso) y estuvo saqueándolo a su gusto, impunemente, mientras vivió. Olvidando esto, casi a renglón seguido cuenta Quevedo la verdadera historia: el manuscrito que le compró al librero tenía aprobación de Ercilla (muerto antes que Herrera) y estaba listo para la imprenta.

En todo caso, la afinidad entre Herrera y Torre es algo que salta a la vista. La cuestión es: ¿quién fue primero? Coster, en 1925, concluyó que el primero fue Herrera. María Luisa CERRón concluye lo contrario: Quevedo se habrá equivocado en cuanto a la enorme antigüedad de Torre, pero no en cuanto a su influencia sobre Herrera. Acusa a Coster de haber procedido a la ligera por "llevar la contraria" a Quevedo, pues "no consigue probar la primacía cronológica de Herrera”, siendo así que, según ella, "tenemos constancia de que las Obras de Francisco de la Torre son anteriores a 1572", y apenas dos de las composiciones de Herrera que aquí interesan pueden fecharse antes de 1577. Pero la idea de que las poesías de Torre son "anteriores a 1572" no puede sostenerse en pie. Coster habrá procedido más por intuición que por otra cosa, pero tenía razón. Yo agrego esto: se desconocía a Torre en España porque era un oscuro vecino de Santa Fe de Bogotá. Los infinitos manuscritos poéticos que corrían en España y su imperio eran sólo de autores españoles. Torre, no representado en ningún cancionero manuscrito de la época, pudo en cambio conocer a Herrera y a otros a medida que iban mereciendo ser copiados en manuscrito. En el caso de Herrera, las seis composiciones suyas que hay en las Flores de baria poesía (1577) frente a las ochenta de Cetina, etc., dicen claramente en qué momentos comenzó su difusión. Torre debe de haber comenzado a escribir después de

${ }^{29}$ La retórica de Quevedo recuerda no poco la de Prete Jacopín, —sobre el cual puede verse Alatorre, pp. 328 ss. Pero Prete Jacopín atacó a un Herrera vivo y capaz de contestar a los insultos (como en efecto sucedió), mientras que Quevedo estalla en ira contra un poeta muerto más de treinta años antes. 
1577. Además, como no sabemos en qué año mandó sus Obras a Madrid para que se imprimieran, hasta pudo conocer la impresión de los Versos de Herrera, hecha en 1582.

Dice también Cerrón que Coster "no hace una comparación exhaustiva entre la lírica de uno y otro", mientras que ella sí la hace, y su conclusión es que "al menos catorce de las poesías de Herrera —ninguna de ellas, curiosamente, analizada por Coster- pueden ser consideradas como una «variación» de otras de Francisco de la Torre". Pero esta formulación se funda en el parti pris de la anterioridad de Torre. Son muy de agradecerle a Cerrón sus "exhaustivas" notas 246 y 247, pero un análisis de sus datos puede perfectamente arrojar este resultado: que varios de los sonetos de Torre son "variaciones" de sonetos de Herrera. Por algo Coster estuvo tentado a creer que Herrera y Torre eran una sola persona (supra, nota 23).

A nadie, que yo sepa, se le ha ocurrido que fray Luis de León haya hecho "variaciones" sobre temas de Torre. No hay duda de que fray Luis es anterior. Y también lo es Herrera. Las reelaboraciones de sonetos herrerianos son de la misma índole que la reelaboración de la Oda a la vida retirada:

Del monte en la ladera por mi mano plantado tengo un huerto, que por la primavera, de bella flor cubierto, ya muestra en esperanza el fruto cierto;

y como codiciosa

por ver y acrecentar su hermosura, desde la cumbre airosa una fontana pura hasta llegar corriendo se apresura;

y luego, sosegada, el paso entre los árboles torciendo, el suelo de pasada de verdura vistiendo y con diversas flores va esparciendo.

El aire el huerto orea y ofrece mil olores al sentido; los árboles menea con un manso ruido que del oro y del cetro pone olvido.
De la nevada y llana frente del levantado monte arroja la cabellera cana del viejo invierno, y moja el nuevo fruto en esperanza y hoja; deslízase corriendo por los hermosos mármoles de Paro, las alturas huyendo, un arroyuelo claro, de la cuesta beldad, del valle amparo; corre bramando y salta, y codiciosamente procurando adelantarse, esmalta de plata el cristal blando con la espuma que cuaja golpeando... El regalado aliento del bullicioso Céfiro encerrado en las hojas, el viento enriquece y el prado, éste de flor, aquél de olor sagrado. 
Es, por lo demás, el mismo tipo de reelaboración que hizo Torre del soneto de Garcilaso (supra, pp. 45-46). Torre sigue a quienes lo han precedido, pero a su manera. Las versiones del italiano, dice CERRón (cf. supra, p. 45), nos dan la oportunidad de calibrar la originalidad de Torre. Lo mismo, exactamente, puede decirse de sus imitaciones/adaptaciones de Garcilaso, fray Luis y Herrera. Torre se extrema, Torre va más allá. Versos como "de la cuesta beldad, del valle amparo" o como "éste de flor, aquél de olor sagrado" ya casi suenan a Góngora. Y si a los sonetos se agregan las seis canciones con comiato, las tres odas en liras garcilasianas, las octavas y los versos sueltos, se verá de manera aún más nítida la asidua relación de Torre con sus predecesores.

Eppur... Tenemos que volver a su originalidad, tan visible, tan nítida como la de fray Luis de León. El tema de la "vida retirada" no es original de fray Luis (ya el marqués de Santillana lo había tomado de Horacio), pero iqué sello tan personal le estampó! La oda “QQué descansada vida...!” nos da la tónica de fray Luis. En ella están, como reunidas en un acorde, las notas esparcidas en las demás; está el fray Luis en conflicto con el mundo, anheloso de paz interior pero bien metido en el mundanal ruido de la Universidad de Salamanca. Es lo primero que nos viene a la cabeza cuando decimos "fray Luis de León". Tampoco el tema de la "cierva herida" es original de Torre ${ }^{30}$, pero ¡qué suyo lo hizo! La tónica de Torre está en la canción "Doliente cierva, que el herido lado...", que es también como un acorde (en tono menor) de varias notas. Esa cierva reaparece en otras composiciones suyas, como la oda " $¿ V i s t e$, Filis, herida/ cierva...?" y el soneto "Filis, no busca desangrada cierva/ con más ardor el agua...”. En la canción está el Francisco de la Torre solitario en Santa Fe de Bogotá, retraído, con su melancolía, su ternura, sus obsesiones, sus ensueños de hermosura ("...cuando de verde mirto y de floridas/ violetas, tierno acanto y lauro amado/ vuestras frentes bellísimas ceñistes...”). Es la primera poesía en que pensamos cuando decimos "Francisco de la Torre"31. Y al lado de la cierva herida está

30 Véase María Rosa Lida, "El ciervo herido y la fuente", RFH, 1 (1939), 31-52 (las pp. 38-43 están dedicadas a Torre). También PÉrEz-Abadín, p. 80, nota 99.

${ }^{31}$ Un verso de esta canción dio a José Ricardo Morales el título para su antología de Torre en la hermosa colección "La Fuente Escondida" (Cruz del Sur, Santiago de Chile, 1943): Del crudo amor vencido. Allí leí por primera vez a Torre. 
la noche. Torre es el gran precursor del género "Nocturno" que los poetas modernistas tomaron del romanticismo alemán a través de la poesía francesa. El Francisco de la Torre bogotano me parece muchísimo más convincente que el jesuita español cuya candidatura propuso Antonio Blanco (cf. supra, nota 23): los jesuitas de aquellos tiempos vivían forzosamente en una comunidad y eran gente de vida activa. Faltaba mucho para que fuera posible un Hopkins. (Francisco de Medrano prefirió ahorcar la sotana).

Es muy fácil encontrar datos autobiográficos en fray Luis. Nos habla muy concretamente, por ejemplo, de su amor a la música, y hasta entrevera en sus versos el nombre de sus amigos Felipe Ruiz, Pedro Portocarrero, Juan de Grial y el músico Salinas. Torre no nos comunica otro dato autobiográfico que el de esa soledad que lo deja abandonado por completo al ensueño poético, fuera de sí, enajenado. Francisco de la Torre fue un "raro", y él estaba consciente de ello, y quiso que sus lectores lo supiéramos. No puede ser otro el sentido del epígrafe que puso "en la primera hoja" del manuscrito comprado por Quevedo: Delirabam cum hoc faciebam, et horret animus nunc, traducido así por Quevedo: "Con frenesí escriví esto; ahora se me escandaliza el ánimo". Torre ha copiado (¿o mandado copiar?) sus versos, los ha distribuido armoniosamente en cuatro "libros" y está a punto de mandarlos a España con la esperanza de que se los impriman. Y entonces, al releerse, le salen del alma esas palabras que significan: "Al escribir estas poesías estaba yo instalado en la locura, enajenado; ahora, al considerarlas serenamente, soy yo el primero que se espanta" 32 .

Una expresión "física" de la rareza de Torre es su versificación. Ni Herrera ni Lomas Cantoral ensayaron metros nuevos. Fray Luis introdujo en sus traducciones de Horacio dos novedades: la lira "agrandada" $a B a B c C$ y la lira "achicada" $A b A b$. Pero las innovaciones de Torre son más, y más impresionantes: desde luego, las estrofas de cuatro versos sueltos, tres endecasílabos y un heptasílabo, que Menéndez Pelayo llamó "turrianas" 33 , y

32 José Ricardo Morales tuvo el acierto de encabezar con este epígrafe, en página especial, su mencionada selección de poesías de Torre.

${ }^{33}$ En su edición de Clás. cast. dice Zamora Vicente que Torre "empleó, seguramente por vez primera en nuestra literatura, la estrofa sáfico-adónica”, lo cual es disparate. La estrofa sáfico-adónica, empleada ya por Antonio Agustín en 1540, termina con un pentasílabo. (Cf. MenÉndez Pelayo, Estudios 
también el empleo de heptasílabos sueltos en las odas 5 y 6 del libro I (novedad doble: el heptasílabo como metro autónomo y la ausencia de rima) ${ }^{34}$ y el de "cuartetillas" hexasilábicas $a b b a$ en nueve de las diez endechas que constituyen el libro III, intitulado "De los versos adónicos"35 (extraordinaria predilección). A estas tres innovaciones cabe añadir la rara "polimetría" de las tres últimas églogas del libro IV (La Bucólica del Tajo). Están hechas en estancias de canzone, como la Égloga I de Garcilaso, pero Torre no se ciñe a las reglas y hace cambios en la estructura métrica cuando hay, por ejemplo, tránsito de la materia narrativo-descriptiva al discurso en primera persona ${ }^{36}$.

\section{"Castizos" y "Culteranos"}

Quevedo, dice CerRón, p. 83, "se llevó el secreto de la verdadera identidad de nuestro poeta a la tumba". No nos consta que conociera esa "verdadera identidad", pero el haber suprimido la aprobación de Ercilla puede ser indicio de que sí la conocía, aunque no fuera de manera precisa. Es verdad que las aprobaciones de Vander Hammen y Valdivielso hacían innecesaria la de Ercilla (quizá ya "inválida" por vieja), pero bien hu-

y discursos de crítica histórica y literaria, ed. de 1942, t. 6, pp. 410-411.) Torre sustituyó el "artificial" pentasílabo por el familiar heptasílabo, compañero fiel del endecasílabo: “¡el huevo de Colón!”, comenta J. L. Estelrich, “Adaptaciones de la métrica clásica”, Rev. Contemporánea, Madrid, 133 (1906), $3^{\text {a }}$ entrega. CARAmuel reproduce en su Rhythmica (Roma, 1665, p. 533) algunas estrofas turrianas, - -las cuales no parecen haber tenido éxito, y sólo revivirán durante la era neoclásica.

34 Villegas será gran cultivador del heptasílabo como metro autónomo, pero sus cantilenas y sus versiones de Anacreonte llevan siempre rima. El heptasílabo va a ser el metro característico de las "anacreónticas". La anacreóntica "De tus rubios cabellos...", que Serrano (Parnaso, t. 7, p. 370) atribuyó "sin ningún fundamento" a Cetina (como dice Antonio Prieto, La poesía española del siglo xvi, Madrid, 1984, p. 171), bien puede ser del siglo xviII.

35 Esto es curioso, pues el adónico tiene cinco sílabas (un dáctilo y un espondeo). La única excepción es la endecha 2, romancillo (véase supra, nota 24). Los antecedentes que conozco son unas coplas de siete versos abab/abc de fray Ambrosio Montesino (Romancero y cancionero sagrados, ed. Sancha, p. 420b) y las "octavillas" abab/abba y abba/acca de Hurtado de Mendoza. Pero nadie había hecho "redondillas" de hexasílabos.

${ }^{36}$ En la égloga 6 hay cambio a partir de la estancia 19; en la égloga 7 hay cambio en la estancia 4, y de nuevo en la 10; y en la égloga 8 hay cuatro cambios: estancias 7, 11, 12 y 17 . 
biera podido reproducirla Quevedo, y con honores, pues Ercilla seguía siendo un poeta muy estimado. La razón de que no lo haya hecho bien puede ser que lo que allí se decía estaba en contradicción con la tesis de la enorme antigüedad de Torre, y lo mejor era silenciar tan molesto testimonio 37 . En fin, "enredó tan bien los hilos que llevaban al verdadero Francisco de la Torre, que consiguió legarnos uno de los problemas de identidad más apasionantes y contradictorios de la historia de la literatura española" (CERRón, p. 85).

Dice también Cerrón, p. 66, que Quevedo editó a fray Luis y a Quevedo "para cargar contra los andaluces", puesto que ataca a Fernando de Herrera. Pero yo no veo que lo ataque por andaluz: lo ataca por "culto", por precursor de Góngora. Y el ataque a Herrera sería anacrónico si no se tratara en realidad de un ataque a Góngora. Herrera era una antigualla y Góngora un fenómeno vivito y coleando, y su fama se estaba extendiendo como mancha de aceite: acababan de imprimirse (1630) las Lecciones solemnes de Pellicer, que daban a Góngora el rango de poeta consagrado, digno de comento (a la par de Juan de Mena y de Garcilaso) ${ }^{38}$. En la Aguja de navegar cultos (1625), en el Discurso de todos los diablos (1627) y en La culta latiniparla (1629), sátiras plagadas de chistes a veces muy ingeniosos, no hay tampoco la menor alusión al andalucismo de Góngora.

Uno de los chistes famosos está en el terceto suelto que sirve de remate a la Aguja de navegar cultos: "mientras, por preservar nuestros Pegasos/ del mal olor de culta jerigonza,/ quemamos por pastillas Garcilasos". Garcilaso, el diáfano, el de vocabulario limpísimo, es la mejor pastilla de olor contra la fetidez del gongorismo. En la silva "Alguacil del Parnaso, Gon-

37 Una hipótesis: Ercilla había aprobado en 1582 la edición de las poesías de Herrera. La aprobación de las de Torre bien puede ser posterior, y quizá en ella había una mención elogiosa de Herrera, igualmente molesta para Quevedo. Sobre la aprobación de las poesías de Herrera por Ercilla cf. Alatorre, pp. 329-330.

${ }^{38}$ En la dedicatoria del fray Luis esgrime Quevedo contra los cultismos de Góngora un pasaje de Propercio que termina: "et cane quod quaevis nosse puella velit". En el prólogo a Torre vuelve a lanzar ese dictum contra los cultismos de Herrera (y, al parecer, cita de memoria: "Scribe quod quaevis nosse puella vellit"). Quevedo quiere hacer pasar al refinadísimo Propercio por enemigo de los cultismos; pero lo que Propercio dice no es "No digas palabras cultas", sino "No te metas en cosas serias cuando te diriges a mujeres". 
gorilla..." 39 reaparece el chiste de las pastillas de olor, y enriquecido: se nos cuenta cómo en cierta ocasión ocupó Quevedo una casa en que antes había vivido Góngora, con lo cual "quedó la casa y barrio todo/ oliendo a Polifemos estantíos.../ y con tufo tan vil de Soledades,/ que para perfumarla/ y desengongorarla/ de vapores tan crasos,/ quemó como pastillas Garcilasos" 40 .

Las obras de Garcilaso no necesitaban una nueva edición, pues nunca habían dejado de estar a la venta ${ }^{41}$. En la intención de Quevedo, la publicación de las poesías de fray Luis y de Torre iba a ser un refuerzo para acabar por siempre jamás con el tufo gongorino. Ahora sabemos que el "gongorismo" vivió con buena salud muchos decenios más, y que, un siglo después de los embates de Quevedo, murió de viejo. Ni fray Luis ni Torre volvieron a ser editados hasta la segunda mitad del siglo XVIII (el primero por Mayáns en 1761, el segundo por L. J. Velázquez en 1753).

(Con la misma intención combativa, un amigo de Quevedo, Luis Tribaldos de Toledo, había publicado en dos ediciones sucesivas de Lisboa, 1625 y 1626, las poesías de Francisco de Figueroa, otro poeta de los buenos tiempos, los aún no contaminados ${ }^{42}$. Y Figueroa tampoco volvió a imprimirse hasta 1785.)

${ }^{39}$ Esta silva es una de las composiciones satíricas que se encuentran exclusivamente en el ms. 108 de la Biblioteca de Menéndez Pelayo. RoberT Jammes, ed. cit. de las Soledades, pp. 676 y 694, sostiene con mucha razón (y mucho tacto) que esas composiciones son apócrifas: el autor es seguramente Jusepe Antonio González de Salas.

40 El muy citado soneto inicial de la Aguja, "Quien quisiere ser Góngora en un día/ la jeri aprenderá gonza siguiente...", que termina diciendo que "pastores y gañanes.../ hacen ya Soledades como migas", fue maquillado a la hora de imprimirlo: "Quien quisiere ser culto en solo un día..." y "hacen ya cultedades como migas".

${ }^{41}$ La edición de 1622, con notas de Tomás Tamayo de Vargas, es ajena a la querella gongorina: en sus comentarios elogia Tamayo por igual a Quevedo ("exemplo de las ingeniosidades de los nobles de nuestra nación") y a Góngora ("ilustre ingenio..., nuestro amigo"). Véase Alatorre, pp. 355-360.

42 Para la relación entre Tribaldos y Quevedo véase Q.-Verso, pp. 650, 748 y 1170. Tribaldos no menciona a Góngora, que aún vivía, pero se vale de procedimientos sinuosos para empequeñecerlo. No sólo cuenta con grandes ponderaciones la historia del manuscrito que publica, lleno de cosas "dignas de perpetua recordación" ahora felizmente rescatadas del olvido - el manuscrito estuvo un tiempo en manos de don Antonio de Toledo, el cual se lo obsequió a Tribaldos, y éste al conde de Villamediana 
La dedicatoria de las Obras de fray Luis, que de hecho es un prólogo, comprende dos partes. La primera, bastante larga, está empedrada de textos de autores griegos y latinos (y dos modernos: Erasmo y Francesco Andreini) que definen lo que es el escribir bien; fray Luis se atuvo a esos preceptos, y así sus versos son "el singular ornamento y el mejor blasón de la habla castellana"; pero la exaltación de fray Luis va trabada, desde el párrafo primero, con el vituperio de los "charlatanes de mezclas", introductores de voces "advenedizas y desconocidas", que se llaman cultos "siendo temerarios y monstruosos", "vanos o escandalosos". La segunda parte es más breve: en ella menciona Quevedo dos particularidades de la lengua de fray Luis que él, obviamente, siente también como "advenedizas y desconocidas": el hipérbaton, que es una "mala invención", y el "partir las voces" (o sea la "cisura" o encabalgamiento: "y mientras miserable / mente se están los otros abrasando..."), "cosa que disuena y bien áspera al oído y a la vista". Pero se las arregla para edulcorar la crítica a fray Luis diciendo que en grandes poetas, comenzando con Píndaro, hay "cisuras", y en grandes poetas, comenzando con Virgilio, hay hipérbatos ${ }^{43}$. ¡Hasta el Sol tiene manchas!

("mi discípulo el mal logrado señor don Juan de Tassis"), y éste a don Vicente Noguera, y éste de nuevo a Tribaldos, para la impresión-, sino que en la portada llama a Figueroa "laureado Píndaro español", título que daban a Góngora sus admiradores. En la dedicatoria a Noguera dice Tribaldos algo enigmático: las obras de Figueroa "salen a luz de las tinieblas a que, por culpa de quienes menos devieran en ella incurrir, estaban condenadas". Hacia 1580 Figueroa era conocido por Herrera y por Prete Jacopín, pero evidentemente las copias se habían hecho raras en 1625. José LuIs Gotor, "Apuntes para una edición crítica de Francisco de Figueroa”, en el citado Homenaje a Eugenio Asensio, pp. 225 ss., no menciona sino tres manuscritos conocidos. Al morir Figueroa, en 1602, hacía muchos años que no escribía versos. Todo lo que hizo pertenece a sus años italianos (cf. infra, p. 60); al regresar a Espana, dice Tribaldos, "ya no tratava de Poesía, sino de materias de diferente punto, según la madureza de su edad". Otros poetas de la "buena" época editados póstumamente por admiradores son Castillejo (1573), Gregorio Silvestre (1582), Acuña (1591) y Diego Hurtado de Mendoza (1610), cuya Guerra de Granada fue publicada por nuestro Tribaldos (1627). Otros no tuvieron tanta suerte: la primera edición de Sebastián de Horozco es de 1874, la de Cetina de 1895 y la de Alcázar de 1910.

43 "Y aun desta mala invención no han sido autores los que presumen de serlo”. ¡Ni siquiera el famoso hipérbaton de Góngora es creación suya! Como ejemplo de "esta demasía" pone Quevedo un verso de Figueroa y otro de Aldana ("tantas le viste flores, que parece...", tan gongorino avant 
El prólogo a las Obras de Torre es mucho más corto, y se dedica casi por completo al problema del vocabulario culto. Herrera, dice Quevedo, emplea arcaísmos ridículos, no tiene ni pizca de originalidad, es un ladrón, y cuando quiere dárselas de original desbarra ${ }^{44}$. Hace dos listas: la primera incluye palabras "raras" de Herrera, como apena, mientra, aura, ostro y ornar, que, por haber sido empleadas antes por el exquisito Francisco de la Torre, quedan ipso facto absueltas 45 ; la segunda lista contiene voces exclusivas de Herrera que, ésas sí, quedan condenadas sin remisión, o por excesivamente cultas o por ser "de composición áspera": cuitoso, pensoso, ovoso, sañoso, dudanza, espirtu, poción, ufanía, pavor, relazar, ensandecer, trayo 'traigo', vo "voy', do 'donde' y las construcciones "crispar de ojo", "giro del fuego", "porfioso desvarío" y "con puro lampo"46. Es notable la impaciencia que se trasluce en estas censuras. Pero la cosa es muy explicable: cada vez que Quevedo dice Herrera, hay que entender 'Góngora'. Al llegar, pues, al capítulo "Vocabulario",

la lettre), pero pasa en silencio versos de fray Luis como "ni de la puesta al bebedero/ sabrosa miel cebado" (oda a Querinto). - Sobre las "cisuras" véase infra, pp. 65-66.

44 Claro que lo dice con melosos eufemismos: "divino ingenio", etc. Cf. supra, p. 48.

45 En esta lista están también la alma (o sea l'alma), corona, perdimiento, conduzir, cuitado, despiadado, mustio, desparcir y cerco, voces para las cuales no necesitaba Herrera el presunto modelo de Torre (cf. por ejemplo desparcir en Garcilaso, Égloga III, 225, y cerco en el propio Quevedo, soneto "Por ser mayor el cerco de oro ardiente...") y —el colmo- le cuelga a Herrera un par de giros que están solamente en Torre: "yerto invierno" (I, oda 1, v. 42) y "errar la selva”, o sea errar transitivo (I, canción l, v. 96).

46 Para esta lista utilizó Quevedo casi íntegramente las "apostillas" que había puesto en su ejemplar de los Versos de Herrera (edición de Pacheco, 1619), y que pueden leerse en Q.-Prosa pp. 1587-1590. (En el prólogo a Torre omite clarar, crinar, membranza, estó "estoy' y las expresiones "alma belleza" y "el cano rayo"; en cambio, añade relazar, pavor, "lasa voz" y "giro del fuego".) Las primeras apostillas critican el muy elogioso prólogo de Francisco de Rioja a Herrera. Dice Rioja que Herrera "verdaderamente fue el primero que dio a nuestros números, en el lenguaje, arte y grandeza"; y apostilla Quevedo: "Miente el idiota" (cf. supra, nota 19). Prosigue Rioja: "También redujo otras voces a su entereza, que la licencia o inorancia popular había cortado y disminuido", y apostilla Quevedo: "De Torre primero lo aprendió". - Entre tantas censuras llaman la atención dos juicios elogiosos, sobre todo el de la expresión "eterno y sacro río", comentada así: "Voz felizmente introducida". (No es disparatado pensar que Quevedo, malgré lui, admiraba a Herrera. Su soneto "Cargado voy de mí; veo delante..." se inspira en el de Herrera, "Subo con tan gran peso quebrantado..."). 
se esfuerza por pescar en Herrera algo aplicable a Góngora, y, en verdad, la cosecha es magra ${ }^{47}$. Su lista está inflada: palabras como ufanía y sañoso eran normales, y pavor se encuentra en Lope de Vega. Y es tramposa: ni a Herrera ni mucho menos a Góngora puede aplicarse la burla de las formas do y vo, elegancia absurda — dice Quevedo-, pues "consta no ser otra cosa sino no caber en el verso la[s] palabra[s] adonde y voy", ni tampoco la de espirtu, "síncopa que no tiene otro misterio sino que en el verso no cabe espíritu" 48 .

El maestro José de Valdivielso, autor de la segunda aprobación de las Obras de Torre, se limita a decir que éstas han sido "aprovad [a]s por don Alonso de Ercila $[s i c]$ y don Francisco de Quevedo..., y aviéndolas aprovado por el Ordinario don Lorenço Vander Hammen..., no necesitan de otra recomendación, pues ninguna será más calificada que la deste triunvirato de ingenios". (Muy probablemente Valdivielso ni siquiera leyó en serio a Torre; en 1630 era ya muy viejo.) La aprobación de Vander Hammen es un continuo aplauso: las poesías que Quevedo "pretende dar a la estampa" son una muestra excelente de "propiedad y pureça", como que se escribieron "en aquellos [felices tiempos] en que se sabía bien y se hablava mejor"; ahora se hacen versos que ya ni parecen estar en español, lo cual "nace de parecerles a algunos ignorantes deste tiempo que es humilde el lenguage castellano si no le ponen afeytes de vozes nuevas", y así lo están corrompiendo ${ }^{49}$.

47 Donde suelta una buena andanada de voces genuinamente gongorinas (excepto el caricaturesco purpuracía) es en el soneto "Quien quisiere ser Góngora en un día..." (o, en versión "bowdlerizada", "Quien quisiere ser culto en solo un día..."). La lista de voces comienza en el verso 3: fulgores, arrogar, joven, presiente, donde Quevedo aprovecha íntegramente lo que dice Góngora hacia el comienzo de las octavas "Era la noche..." (ed. Millé, núm. 407): "Fulgores arrogándose, presiente...". (En esas octavas hay otras voces de la lista: canoro, conculcar, erigir, impedir, librar, nocturno.) IGNAcio Arellano, Poesía satírico burlesca de Quevedo, Pamplona, 1984, pp. 187188, nos ofrece una extensa "Lista de cultismos en los sonetos de sátira antigongorina o culterana".

${ }^{48}$ Quevedo olvida mañosamente que espirtu es frecuente en el gran dechado, Garcilaso, como también do y estó (soneto 1: "mas cuando del camino stó olvidado,/ a tanto mal no sé por dó he venido”).

${ }^{49}$ Vander Hammen se carteó con Quevedo (Q.-Prosa, pp. 1731 ss., epístolas $69,70,75,79)$ y, como escribió una elogiosa aprobación de la Perinola, no se le ahorran palos en el Tribunal de la justa venganza (Q.-Verso, p. 1100): "En cuanto a la [aprobación] de don Lorenzo Vander Hammen, dijeron que la condenaban y condenaron por de hombre apasionado y poco pru- 
En nada de esto - repito lo que antes dije- puede verse una batalla de castellanos contra andaluces. Es una batalla de "sensatos" (quienes escriben de manera inteligible) contra "insensatos" (los locos que escriben de manera ininteligible); concretamente, una batalla de Quevedo contra Góngora. No hay razón para pensar que durante decenios y decenios hubo una continua guerra literaria entre castellanos y andaluces, como la que había habido entre los de Lancaster y los de York. El castellano Lope era amigo del andaluz Arguijo; los Argensolas son ajenos al gongorismo, pero no por castellanos, pues eran aragoneses; y Pedro Espinosa incluye en sus Flores (1605) a andaluces como Góngora y Luis Martín de la Plaza lo mismo que a castellanos como Lope y Quevedo.

Quien lanzó o propaló el mito de las dos "escuelas" fue Menéndez Pelayo. Hubo, según él, una "guerra civil entre sevillanos y salmantinos", cuyo "primer chispazo" fue el soneto en que Jerónimo de los Cobos se burló de las notas del Brocense a Garcilaso — soneto a que "respondió el Brocense por los mismos consonantes" ${ }^{\circ 0}$, tras lo cual menciona la rabiosa diatriba de Prete Jacopín. Antes ha dicho que las Anotaciones de Herrera fueron, "digámoslo así, el código de la escuela sevillana en su segunda época, [la de] madurez y completo desarrollo", que por lo visto tuvo larga duración ${ }^{51}$. Todo esto merece un examen

dente en alabar con tan ostentoso y locuaz boato a un sujeto tan mal opinado [como Quevedo]...; también dijeron que, atento a los hipérboles con que el dicho don Lorenzo Vander Hammen lo abona y engrandece, que su apología o elogio sea tenida por fabulosa”, etc.

50 M. Pelayo, p. 65, nota. Herrera reproduce parte de una traducción de Horacio por Jerónimo de los Cobos (Anotaciones, 1580, p. 109); otra traducción horaciana del mismo se copia en el f. 56 de uno de los cartapacios salmantinos reseñados por Menéndez Pidal en BRAE, 1 (1914), pp. 307 ss. El soneto se burla del Brocense por su empeño en descubrir "fuentes" a Garcilaso. Tiene que ser anterior a 1580, pues Herrera es aún más "fuentista" que el Brocense.

51 M. Pelayo, p. 62. La "primera época”, según eso, fue muy breve (pues entre el soneto de Cobos y el ataque de Prete Jacopín median pocos años). En las Flores de Espinosa encuentra M. Pelayo (pp. 92-93) señales de que la contraposición continuaba en 1605: las traducciones andaluzas que acogió Espinosa son "parafrásticas y libérrimas, palabreras y poco horacianas": ¡qué diferencia con las del salmantino fray Luis! Pero la verdadera contraposición, pienso yo, es la de traductores concisos y traductores parafrásti- 
detenido. Caracterizar las Anotaciones como "código" de los sevillanos es una ligereza. Un Cervantes, un Lope, las encontraron admirables. Y lo que hubo no fue propiamente guerra, sino duelo entre un castellano y un sevillano (Prete Jacopín y Herrera). Después, pasado medio siglo, hubo otro sonado duelo entre un castellano y un cordobés (Quevedo y Góngora).

Es muy burda la manera como a los poetas de la época áurea se les ha colocado una de dos etiquetas, tan distinguibles una de otra como el rojo del azul. Consideremos el caso de Francisco de Figueroa. Es claro que Tribaldos de Toledo imprimió sus versos bajo el signo del anticulteranismo: Figueroa le servía muy bien como ejemplo de lenguaje "de los buenos tiempos". Tal es el deleznable fundamento de algo que ha adquirido categoría de axioma: que a Figueroa le corresponde un lugar en el bando "castellano" (o sea, según la mente de don Marcelino, en el lado "bueno"). Pero Figueroa escribió sus versos en Italia, perteneció a círculos italianos, escribió poesías en italiano; fue en Italia donde lo llamaron "divino". Y una muestra curiosa de su entrañable italianismo es que haya escrito poemas en "versos alternados", uno en italiano y otro en español. Ahora bien, si Herrera hubiera sido el autor de tales versos, no es difícil imaginar la andanada crítica que Prete Jacopín y después Quevedo le hubieran lanzado. Pero sucedió al contrario. El escandalizado por esa "novedad", tan enemiga de la pureza del lenguaje castellano, es Fernando de Herrera. Calla, discretamente, el nombre de Figueroa, y se esmera en que su crítica sea de carácter general: "Se han inclinado muchos [!] a entrelazar versos italianos i españoles..., mescla mal considerada i agena de la prudencia i decoro poético, i grandemente huida i abominada de todos" (Anotaciones, p. 173). ¿Qué hace Prete Jacopín? Conocemos sus ideas lo bastante para concluir que también él reprobaba los versos "entrelazados"; y entonces replica que la censura de Herrera está motivada "sin duda" por "la invidia de algunos versos castellanos e italianos que ha hecho Francisco de Figueroa"52.

cos: Medrano, andaluz, es conciso; Villegas, castellano, es parafrástico. Véase A. Alatorre, "Notas filológicas en torno a Luis Martín de la Plaza", NRFH, 45 (1997), 438-439.

${ }^{52}$ No son "algunos versos", como dice Prete Jacopín para atenuar la cosa, sino muchos: una elegía en octavas, dos elegías en tercetos y un soneto. Herrera utiliza el recurso retórico inverso: exagera cuando dice que "muchos" españoles les han copiado esa extravagancia a los italianos (entre 
Tamayo de Vargas, que copia a Prete Jacopín, es más cauto: "Esto quizá lo dixo por Francisco de Figueroa", pero añade una defensa que Prete Jacopín no se había atrevido a hacer: "[Herrera] no tubo razón [al criticar eso], porque [Figueroa] lo hizo con felicidad". Desde los tiempos de Prete Jacopín hasta los de Tamayo de Vargas ha corrido mucha agua. Tamayo, amigo de Góngora ${ }^{53}$ y también de Quevedo, da la bienvenida a toda "novedad" que redunde en bien de la poesía. Su juicio coincide con el que poco antes había expresado Tribaldos de Toledo en su edición de Figueroa: esos versos alternos "[no merecen] reprehensión, como algunos ignorantes podrán pensar", sino todo lo contrario, porque Figueroa los hizo "con gala".

Figueroa pertenece a una época en que no había el menor barrunto de la muy agigantada oposición entre "salmantinos" y "sevillanos"54. Es la época de las Flores de baria poesía (1577), vasto cancionero en que están representados muchos poetas no andaluces: Acuña, el Duque de Gandía, Figueroa, Damasio de Frías, Montemayor, Laínez, Gregorio Silvestre, Ramírez Pagán, así como Hurtado de Mendoza, andaluz de Granada, pero tan no andaluz como Boscán o Garcilaso. (Si en las Flores predominan los andaluces es porque Sevilla era la verdadera "capital" del Nuevo Mundo, y porque Cetina y Juan de la Cueva vivieron un tiempo en México.)

Menéndez Pelayo estaba absolutamente convencido de la existencia real de las dos "escuelas". A Francisco de la Torre, dice, "corresponde, sin $d u d a$, el segundo lugar [después de fray

los cuales hubo, en efecto, no pocos que mezclaron latín e italiano, o italiano y provenzal: cf. el ejemplo que trae Rengifo, Arte poética, 1592, cap. 51). Seguramente conocía Herrera el soneto ítalo-español que publicó Ramírez Pagán en su Floresta (1562), pero quizá no leyó el "capítulo" trilingüe (español-latín-italiano) de Torres Naharro, ni tampoco las octavas bilingües de Aldana, cuyas obras no se imprimieron hasta 1589/91. Y no conozco más ejemplos.

53 Véase Alatorre, pp. 332-333, y cf. R. Jammes, ed. de las Soledades, pp. 629-630.

54 Lo único evidente es que durante algunos años hubo en Salamanca un pequeño grupo de "secuaces" de fray Luis, como el Brocense, el maestro Termón, Almeida y Alonso de Espinosa, a los cuales —o a "algún otro poeta de la misma época y estilo" (M. Pelayo, p. 49) - habrá que atribuir ciertas buenas traducciones de Horacio. De la misma manera, Herrera estaba rodeado en Sevilla de un grupito de "discípulos" como Jerónimo de los Cobos, Diego Girón y Francisco de Medina. 
Luis] entre los poetas de la escuela salmantina" (M. PeLAYo, p. 54); y también: Torre es "segundo en mérito entre los poetas salmantinos, a cuya escuela, y no a la sevillana, legítimamente pertenece". Es lo que han opinado y siguen opinando muchos críticos $^{55}$, por ejemplo María Luisa Cerrón cuando dice que "la poesía del complutense Figueroa [es] inseparable de la de Francisco de la Torre en cuanto a escuela lírica", y que "fuera o no fuera el poeta [Torre] de Salamanca, es indudable que a su escuela poética pertenece" (CERRón, pp. 39 y 50) ${ }^{56}$. Lo que propongo es ver la relación Figueroa/Torre bajo otra luz: los dos muestran "rarezas", los dos escribieron fuera de España (uno en Italia, el otro en Bogotá), los dos son ajenos a la supuesta querella de salmantinos contra sevillanos.

\section{LOS PROBLEMAS DEL “APÉNDICE”}

Los catorce últimos folios de la edición de Torre (del 131 al 144) han hecho correr mucha tinta. Son una especie de apéndice que consta de varios bloques no bien conectados entre sí: 1) prologuillo de Juan de Almeida a un puñado de traducciones poéticas del Brocense; 2) traducciones del Brocense; 3) miscelánea que comprende una traducción del Quid fles? de Horacio y las traducciones del $O$ navis! por Almeida, el Brocense y Alonso de Espinosa; 4) un parrafito narrativo ("Aviendo traduzido tres tan grandes poetas...") que sirve de introducción a 5) una carta de los tres "grandes" traductores a fray Luis, y respuesta de fray Luis; 6) traducción del $O$ navis! por fray Luis de León, y finalmente 7) disertación sobre las "cisuras" o encabalgamientos del tipo "y mientras miserable- / mente..."

${ }^{55}$ Los cuales parecen hacer este silogismo: "Don Marcelino contrapuso la escuela salmantina a la sevillana; don Marcelino es gran autoridad; ergo la contraposición existió". Pero la premisa menor no se sostiene: todos sabemos que don Marcelino adoleció de varias formas de miopía.

56 Cf. M. Pelayo, p. 311: "Al lado de [Torre] debe figurar su amigo [!] Francisco de Figueroa”. Dice Pérez-Abadín, p. 27, nota, que “a juicio de [Cristóbal] Cuevas, La Torre no fue discípulo directo de fray Luis, mientras que Alberto Blecua sostiene el probable conocimiento entre ambos". No me parecen opiniones contradictorias: el "no discípulo directo" es muy conciliable con el "probable conocimiento". (Claro que no es "probable", sino seguro, que Torre conocía por lo menos la oda "A la vida retirada": cf. supra, p. 50 . 
Todo esto va corrido, sin ninguna señal tipográfica de separación (salvo entre los bloques 1 y 2, separados por un espacio en blanco), de tal manera que la traducción del Quid fles? (bloque 3), impresa a renglón seguido de la de un soneto de Veniero por el Brocense (final del bloque 2), parece obra también del Brocense, siéndolo de fray Luis. El error es obvio. Pero todo se aclara si atribuimos a Quevedo los bloques 3 a 7 , que son un cajón de sastre. La atribución a Almeida de estas cinco porciones del apéndice no puede sostenerse. Lo único de Almeida es el prologuillo inicial.

El prologuillo dice: "Aviendo comunicado estos versos con el maestro Francisco Sánchez de las Broças... [aquí su elogio], y teniendo también conocimiento de algunas traducciones suyas..., le supliqué las pusiesse juntamente con ellos" (y el Brocense aceptó). Como el apéndice se imprime inmediatamente después del "Fin de las Obras de Francisco de la Torre" (f. [130]), es natural que se haya entendido que estos versos son los de Torre. Pero no puede ser. ¿Por qué había de consultar Almeida el asunto de los versos de Torre con el Brocense no siendo él el editor, sino Quevedo? Con estos versos, dice Coster, p. 92, Almeida se refiere a los de fray Luis. Los bloques 1 y 2 del "apéndice" iban a ir al final de una edición de poesías de fray Luis al cuidado de Almeida. Éste murió en 1572, pero las poesías fechables de fray Luis son de 1569-157157. El catedrático fray Luis nunca quiso publicar sus versos, pero dejó que sus amigos lo hicieran, siempre y cuando se abstuvieran de mencionar su nombre. Poco después de la muerte de Almeida, al preparar el Brocense su edición de Garcilaso, a medida que hacía las notas se las mandaba a su amigo Juan Sánchez del Mármol. En una carta de comienzos de 1574 le dice el Brocense a ese amigo que acepta sus sugerencias, salvo una: en las notas ha incluido cuatro traducciones de Horacio hechas por cierto poeta, y no ve por qué le aconseja él suprimir una, así que (con perdón) la va a mantener, "por ser del mismo autor que las demás que V.md. no quita, y porque el Autor es conocido, y no le pesará de que se imprima, aunque no consintirá que su nombre se divulgue en este caso, por ser hombre dotísimo, y de quien mucho se espera" (GAllardo, Ensayo, t. 4, col. 449). El título que iba a tener

57 En un manuscrito de la H.S.A. la dedicatoria a don Pedro Portocarrero está fechada en 1580; pero en ella dice fray Luis que las poesías son de sus años mozos. 
la abortada edición de Almeida era seguramente el que adoptó Quevedo: Obras... y traducciones latinas, griegas y italianas. Como final de fiesta, Almeida se proponía dar a conocer algunas muestras de las "buenas y singulares letras" de un gran colega de fray Luis, Francisco Sánchez de las Brozas, autor de obras dignas de publicarse al lado de estos versos ("juntamente con ellos": obviamente los de fray Luis, no los de Torre); van, pues, "algunos sonetos de Francisco Petrarca y otras Odas de Horacio" (otras, porque antes habrán estado las traducidas por fray Luis); y en efecto, lo primero que hay son las traducciones del Rectius vives y del Quis multa gracilis por el Brocense: a Francisco de la Torre no se le puede considerar traductor de Horacio $^{58}$. La explicación de las incongruencias del "apéndice" no puede ser sino ésta.

Quevedo, que mantuvo el prologuillo de Almeida, suprimió el prólogo que éste debió haber escrito, o sea una presentación de las poesías de fray Luis, y en su lugar puso otro prólogo en forma de dedicatoria al Conde-Duque de Olivares, donde lleva agua a su molino por tres canales: la batalla contra la jerigonza de los "cultos", el suntuoso despliegue de erudición retórica, y - last, pero quizá no least - la necesidad de ganarse la voluntad del Conde-Duque. Son, en versión diferente, los mismos tres canales que vemos en su edición de Torre, sólo que aquí la erudición es gramatical, y el personaje homenajeado con la dedicatoria es el yerno de Olivares, joven de 18 años en 1630 , pero astro en ascenso.

Ya Jorge de Sena llamó la atención sobre la imposibilidad de que Almeida, en el bloque 4 del apéndice, haya calificado de "tres tan grandes poetas" a los traductores del O navis!, siendo él uno de los tres ${ }^{59}$. En cuanto a María Luisa Cerrón, lo que encuentra ajeno a la mano de Almeida es el bloque 7 del apéndice, o sea la disertación sobre el encabalgamiento (las "cisuras").

Valdrá la pena ver el asunto de cerca. El bloque 7 comienza así: "En el discurso de estos versos se hallan algunas cisuras que

58 Imitador sí, muy de vez en cuando. Cf. M. Pelayo, pp. 56-57 y 308311. En esos tiempos estaba muy generalizado el amor a Horacio. Dicho sea de paso, una muestra de que la oposición de salmantinos y sevillanos necesita afinarse es que en los dos bandos había horacianos.

${ }_{59}$ Citado por Cerrón, nota 156, la cual desdeña el argumento de manera un tanto sumaria. Ella se atiene a la explicación de Antonio Blanco: que esas palabras "sólo aparecen en la edición de 1631, estando ausentes de los manuscritos". Pero ¿qué "manuscritos” son ésos? 
[parecen violar las leyes métricas]; ya yo he visto disputar esto, y encarecer por cosa [muy] aborrecible esta dissonancia"; pues sepan esos hipercríticos que Horacio practicó la cisura, y no por "necessidad" métrica, sino "por enriquecer la manera del escribir..., elegancia aborrecida de los deste tiempo por no alcançada". A diferencia del estos versos del bloque 1, donde habla Almeida refiriéndose a los de fray Luis, aquí estos versos son los de Torre. Según CERRón, "se hace difícil distinguir quién hace la exposición sobre el encabalgamiento, si Almeida o si el Brocense". Y, como el Brocense era un "gramático", se la atribuye, argumentando que en esa exposición se citan algunos ejemplos clásicos de "cisura" recogidos por Ruscelli en una nota de sus Fiori (1558). Pero estos Fiori (reeditados en 1569 y 1579) estaban igualmente al alcance de Quevedo, el cual, muy según su costumbre, no menciona su fuente ${ }^{60}$. Por otra parte, el Brocense no necesitaba hacer una illustration et défense de las "cisuras", practicadas por contemporáneos suyos, y Quevedo sí necesitaba hacerla, pues "los [lectores] deste tiempo" (los de 1630) los rechazan, - y hacen mal, porque es una "elegancia" de nobilísima prosapia. Téngalo presente el lector cuando se tope con cisuras en estos versos (de Torre) ${ }^{61}$. La apología está en perfecta continuidad con lo que ha dicho Quevedo en el prólogo acerca de los cultismos. Le pide al lector que no tuerza el gesto al toparse con ornar, aura y otras voces así: si las usa Torre están bien (ovoso, pavor, etc. son muy otra cosa). Y está también en perfecta continuidad con lo que ha dicho sobre las cisuras en su edición de fray Luis (cf. supra, p. 56), y hasta da un paso

60 Dice Quevedo: "Trayré algunos lugares donde [Horacio] usa desta manera de elegancia”. El Brocense hubiera citado tranquilamente a Ruscelli, pero a Quevedo le encantaba exhibir erudición vistiendo plumas ajenas.

61 Torre hace cisuras dos veces: en el libro II, soneto 14 ("ordinaria-/ mente") y en el libro IV, égloga 2 ("ligera-/ mente"). Exagera Quevedo al decir que en fray Luis hay "muchas cisuras". Creo que hay sólo tres. - La "cisura" más escandalosa (debidamente notada por Quevedo en el prólogo a fray Luis) es una de Aldana: "corre, no pares, vé, camina, perma- / neciendo siempre en tantas desventuras" (octavas "Sobre el bien de la vida retirada", v. 165). Esta "cisura" está en una tradición italiana más que pindárico-horaciana. Ya en 1332 ANTONIO DA TEMPo (Summa artis rithimici, cap. 72) había tratado "De compositione de uno versu in alium in eadem dictione divisa", con este ejemplo: "Questo ben si comprende ne l'imagi- / ne di qualunca ha nobele sentire"; y ésta se remonta, a su vez, a una Spielerei medieval citada allí mismo: "Mittitur in disco mihi piscis ab archiepisco- / po: non inclino, quia missio fit sine vino". 
más, pues ahora encubre mejor su obvio rechazo personal de las cisuras ${ }^{62}$.

Esta interpretación del famoso "apéndice" es muy distinta de la que hace María Luisa Cerrón (pp. 50-58). Según ella, las poesías que hay allí — las del Brocense, las traducciones del $O$ navis! etc.- no son "apéndice", sino "parte integrante, con pleno derecho, de un volumen que aspiraba a convertirse en remedo de las antologías petrarquistas italianas" (las publicadas por Domenichi, Dolce y Ruscelli), o sea un cancionero salmantino: tras las poesías del "salmantino" Torre venían las de otros salmantinos; pero hubo algún contratiempo, "resultando al final que toda la atención se centra sólo en Francisco de la Torre". Francamente, me parece una explicación fantasiosa ${ }^{63}$. El volumen publicado por Quevedo no es antología, sino "obras completas" de un poeta, al final de las cuales se meten, sin mucho método, otras cosas.

"La cadena de malentendidos que rodea la edición quevedesca", como dice CerRón (p. 61), tiene la culpa de las varias y variadas especulaciones de los críticos. Y justamente ella añade una especulación más. Convencida como está de que la disertación sobre las cisuras (bloque 7) es del Brocense, se ve obligada a explicar por qué estaba en manos del Brocense el manuscrito de Torre. Le hubiera bastado repetir que Torre "pertenece" de manera "indudable" a la escuela salmantina (cf. supra, p. 62), pero ahora entra en detalles. Como está averiguado - según ella- que fue Herrera el imitador de Torre, y no viceversa, lo que falta es imaginar cómo llegó a manos de Herrera el manuscrito de Torre, y supone ella que Juan de Mal Lara, contertulio del Brocense y maestro de Herrera, fue quien sirvió de intermediario. Pero "contertulio" parece excesivo. Lo

62 Una confirmación de que no hubo choque de "escuelas" es que, así como Torre adoptó buen número de los cultismos del sevillano Herrera (no todos), así también imitó las cisuras del salmantino fray Luis (y las empleó con la misma parquedad que él).

63 Según Almeida (bloque 1), las traducciones del Brocense son un añadido, un "fin de fiesta". Las otras cosas (la traducción del Quid fles? por fray Luis y la "competencia" de los traductores del $O$ navis!, bloques 3 a 6 ) hubieran estado muy bien en el cuerpo de las Obras de fray Luis, pero habrá que suponer que no se encontraban en el manuscrito editado por Quevedo y llegaron tarde a conocimiento suyo. (Las Flores de Espinosa, ésas sí que son una antología a imagen de las que "inundaron Italia".) 
que se sabe es que Mal Lara y el Brocense coincidieron en la Universidad de Salamanca (donde fueron alumnos del Comendador Griego) y que se separaron, quizá para siempre, en 1548, año en que Mal Lara regresó a Sevilla y abrió estudio de Gramática, mientras el Brocense continuó en Salamanca ${ }^{64}$. La consecuencia de esta imaginación es que los versos de Torre serían anteriores a 1548, cosa obviamente imposible. Pudo haber correspondencia epistolar entre Mal Lara y el Brocense, pero Mal Lara murió en 1571.

En todo caso, ese punto no será de gran interés para quien esté convencido de la influencia de Torre en Herrera. Da igual cómo conoció éste los versos de aquél. El punto de interés es la historia del manuscrito mismo. Desde luego, si el Brocense - como piensa CERRón ( supra, p. 65) — es el autor de la disertación sobre los dos casos de encabalgamiento que hay en Torre, es que tenía el manuscrito en su mesa; y quien se lo "entregó" fue Almeida, a la vez que le "solicitaba más traducciones" (CERRÓN, p. 85). No dice Cerrón cómo pudo llegar el manuscrito a manos de Almeida ${ }^{65}$. Lo que le importa averiguar es qué ocurrió después, o sea desde por lo menos 1572 (año en que murió Almeida) hasta 1629, cuando Quevedo estaba a punto de mandarlo a la imprenta. Su esfuerzo especulativo ocupa buen espacio del libro (pp. 58-65 y 81). Y lo que imagina es lo siguiente:

El manuscrito de Torre estuvo durante largos años en poder del Brocense, y seguía en 1600 entre los "libros y papeles" suyos que mandó recoger la Inquisición de Valladolid cuando el anciano humanista sufrió un proceso a causa de su libertad de lenguaje. Como el canónigo sevillano Manuel Sarmiento de Mendoza andaba por Salamanca de paso para Valladolid, se le confió la delicada misión de trasladar a Valladolid lo secuestrado. Ahora bien, en la portada de las Obras de fray Luis (1631) se dice que éstas fueron "sacadas de la librería" del canónigo; en vista de ello, "no es muy descabellado" pensar que éste, seguramente amigo de la poesía, secuestró para sí mismo dos de los

64 Cf. Hurtado y González Palencia, Historia de la literatura española, $6^{\text {a }}$ ed., 1949, p. 302. La Declaración y uso del reloj español, primer parto literario del Brocense (1549), va precedida de un "Soneto de Juan de Malara, natural de Sevilla” (Gallardo, Ensayo, t. 4, col. 459).

65 Si Torre era "salmantino", como cree Cerrón, pudo prestarle sus versos a Almeida. Pero igual pudo habérselos prestado directamente al Brocense. 
manuscritos secuestrados: el de fray Luis y el de Torre ${ }^{66}$. Las ambigüedades de Quevedo - "el confundir a Francisco de la Torre con el bachiller Alfonso de la Torre", "el no indicar la procedencia exacta del manuscrito" - se explicarían así: Quevedo, sabedor de la procedencia non sancta del manuscrito, estaba "jugando con fuego". Al sustraer el manuscrito de Torre en momentos en que oficialmente estaba ya en poder de la Inquisición, Sarmiento había violado una "grave responsabilidad". Así, pues, Quevedo tuvo que "ingeniárselas para publicar el volumen dando el mayor número posible de pistas falsas".

Es una imaginación interesante, una reconstrucción - diría yo- novelesca en el sentido bueno y en el malo: en el bueno porque tiene coherencia y dramatismo, y en el malo porque no tiene base. Si Quevedo no indica la procedencia "exacta" del manuscrito, la explicación lógica es que no la conocía ${ }^{67}$. Si no es "descabellado" pensar que Sarmiento cometió un doble y serio latrocinio, no se ve por qué en el caso de fray Luis explica Quevedo la proveniencia del manuscrito mientras en el de Torre se esfuerza por echarle tierra al asunto: tan cargo de conciencia sería lo uno como lo otro ${ }^{68}$.

66 Dice Cerrón (nota 193) que ya Antonio Blanco "asegura" que también el manuscrito de las poesías de Torre (no sólo el de las de fray Luis) procedía de la biblioteca del canónigo; pero su razonamiento va por otros caminos.

${ }^{67}$ No todo lo que dice Quevedo es tramposo. Su relato de cómo halló en casa de un librero el manuscrito de Torre - cet inconnu - tiene todos los visos de la verdad; describe el manuscrito con sus pelos y señales: estaba listo para la imprenta, con prólogo de Ercilla, y al principio había una notable declaración del poeta: Delirabam cum hoc faciebam...

68 Algo más. Hubo dos inventarios de lo que se decomisó al Brocense, uno del 2 y otro del 22 de noviembre de 1600 (A. Tovar y M. DE LA PinTA LLORENTE, Procesos del Brocense, Madrid, 1941, pp. 122-124); en ninguno de ellos hay obras literarias, y con razón, pues lo que mandó "recoger" la Inquisición de Valladolid de casa del Brocense fueron "los papeles o libros escritos de mano... que se hallaren en su poder, rreprobados o sospechosos". Los ejecutores del secuestro, por las dudas, tomaron de la biblioteca, sorprendentemente modesta, hasta cosas muy innocuas (unas "comedias", unas "Etimologías españolas", el Pro Milone de Cicerón...); lo único potencialmente sospechoso era cierta Ecphrasis in Cantica canticorum. Por torpes que fueran los secuestradores, no iban a incluir los manuscritos poéticos. Además, los papeles que llevó Sarmiento de Salamanca a Valladolid iban "cosidos en un lienzo angeo y sellados" (seguramente con lacre). Del proceso del Brocense no quedaría ya ni recuerdo en 1631, y es imposible que los inquisidores de 1631, treinta años posteriores a los que procesaron al Brocense, se pusieran a atar cabos en perjuicio de Sarmiento. Y ¿̇ómo suponer 
Las complicaciones con que se han topado Cerrón y otros críticos nacen de la confusión entre el estos versos al comienzo del bloque 1 (Almeida refiriéndose a los de fray Luis) y el estos versos al comienzo del bloque 7 (no Almeida, ni el Brocense, sino Quevedo ${ }^{69}$ refiriéndose a los de Torre).

En lugar de "pistas falsas", como dice Cerrón, prefiero hablar de frangollonería y trapacería. Ejemplo de lo primero es el caos mismo del "apéndice". Y los ejemplos de lo segundo abundan. Quevedo sabe que Torre no es poeta del siglo Xv, pero le conviene hacer la comedia para así lanzar contra Herrera (i.e. contra Góngora) un primer puñetazo: "Aprende, estúpido, a escribir como Dios manda, y reconoce la grandeza de este antiquísimo poeta”. Claro que la mentira de Quevedo estaba como prendida con alfileres; se deja en silencio la consecuencia lógica: que también Garcilaso y Boscán plagiaron a Torre (cf. supra, p. 42, y el final de la nota 20). Lo que le importaba era dar palos a Góngora usando a Herrera como cabeza de turco. De ahí la muy arbitraria comparación del vocabulario de Torre con el de Herrera: las "rarezas" de Torre están bien; las de Herrera, mal. Otro tanto se aplica al hipérbaton y al encabalgamiento: si están en fray Luis, en Torre, en Aldana, están bien; si no, no. "Parece raro — dice CERRón, p. 16- que el título de «bachiller» le sea

tan linces en 1631 a unos Inquisidores que en 1600 no se percataron siquiera de que los sellos del saco de anjeo habían sido violados? Cabe agregar lo que dice M. Pelayo, p. 525: "La Inquisición no opuso obstáculo ninguno al desarrollo de la poesía lírica que (entre paréntesis) no le importaba nada". - He aquí, finalmente, algo que parece habérsele escapado a Cerón: el manuscrito de fray Luis editado por Quevedo es muy defectuoso (omite versos, incluye cosas no auténticas, abunda en malas lecturas); es sencillamente imposible que ese manuscrito haya sido el que poseía el Brocense, colega y gran amigo del poeta. ¿Por qué, en vez de imprimir el texto que iba a publicar Almeida (cf. supra, p. 64), prefirió Quevedo un manuscrito moderno y no muy bueno? Quizá porque le convenía adular al canónigo Sarmiento presentándolo como dueño de una biblioteca espléndida. (Para la relación entre Sarmiento y Quevedo véase Q.-Verso, pp. 890 a y $1170 a$.)

69 Según noticias de Cerrón, nota 157, también Antonio Blanco atribuye el bloque 7 al Brocense. Antonio Quilis, "Los encabalgamientos léxicos en -mente de fray Luis de León y sus comentaristas", HR, 31 (1963), pp. 2628, se lo atribuye (como yo) a Quevedo. Dice Cerrón que esta atribución a Quevedo es "imposible", porque la disertación sobre el encabalgamiento "se repite en manuscritos del siglo xvı". Pero, una vez más (cf. supra, nota 59), ¿qué "manuscritos" son ésos? 
dado [a nuestro poeta] solamente en la suma del privilegio y en la portada", pues "en los preliminares, las dos dedicatorias incluidas", no hay tal "bachiller". Claro, lo añadió Quevedo para que coincidiera con "el Bachiller que llaman de la Torre" (el cual no se llamaba Francisco).

Quevedo era capaz de todo. Intrépidamente se presentó ante el mundo como traductor del hebreo, del griego y del francés, y las tres cosas son mentira ${ }^{70}$. La tramposa declaración sobre la antigüedad de Torre, tan conveniente para sus fines, se parece a la que poco antes había estampado en la dedicatoria de las Obras de fray Luis, donde le habla a Olivares, con grandes ponderaciones, de un rarísimo manuscrito no mencionado por nadie (y que, por lo visto, es suyo): la Gaya ciencia (o Arte de trobar) de don Enrique de Villena, y le dice, muy serio, que esta obra muestra con cuánto cuidado, en aquellos lejanos y felices tiempos (los de Juan de Mena), "se estudiaba la lengua castellana, y el rigor y diligencia con que se pulían las palabras" (en el trasfondo están las funestas "novedades" de Góngora), y termina maravillosamente diciendo que, si no se lee la Gaya ciencia, "mal se puede dar razón de las voces tan afectuosas [sic] de las Partidas [de Alfonso el Sabio]"... Pero todo es tortas y pan pintado frente al descaro con que en su España defendida (1609), obra destinada a mostrar al universo mundo cómo España ha estado y está über Alles, dice que "nuestra lengua no tomó de la griega ni de la latina", sino que es una de las 72 originales, las generadas durante la construcción de la Torre de Babel; no sólo no desciende del latín (lo cual sería una especie de desdoro), sino que existe desde antes que el latín y el griego existieran. Es de todo punto imposible que Quevedo, en estado de sobriedad (y no de frenesí), creyera en esa patraña lanzada en 1601 por Gregorio López Madera, chauviniste despistado; pero la acogió y la expuso con lujo retórico y erudito, aun a sabiendas de que en 1606 la había dejado bien refutada el docto Bernardo de Aldrete ${ }^{71}$.

70 Véase, para el hebreo, Raúl Del Piero, "Las fuentes del Job de Quevedo", BdFS, 20 (1968), pp. 17 ss.; para el griego, Sylvia Bénichou Roubaud, "Quevedo helenista", NRFH, 14 (1960), 51-72; y para el francés, RAIMUNDO LIDA, "Quevedo y la Introducción a la vida devota", NRFH, 7 (1953), 638-656 (o en sus Letras hispánicas, México, 1958, pp. 124-141).

${ }^{71}$ Cf. R. Lida, "La España defendida de Quevedo y la síntesis pagano-cristiana”, en Letras hispánicas, pp. 142-148. 
Resumen

Reconozco que me he metido en muchos vericuetos, pero era necesario: una tesis nueva necesita atender a las tesis anteriores, y el terreno cubierto por las ramificaciones de la crítica turriana es muy considerable.

Resumo mi tesis en forma de "entrada" de diccionario enciclopédico: Francisco de la Torre nació a mediados del siglo xvI en Santa Fe de Bogotá, donde parece haber pasado toda su vida. Fue hombre de letras (ostentaba el título de "licenciado") y escribió versos admirables. En 1599 se imprimió en Madrid un soneto suyo, compuesto en Bogotá, pero ya años antes había enviado a España el manuscrito de sus obras poéticas. Éstas estuvieron a punto de publicarse, pero quedaron inéditas durante más de cincuenta años hasta que por fin, en 1631, se imprimieron por iniciativa de Francisco de Quevedo. Las composiciones de Torre tienen mucho en común con las de los poetas españoles contemporáneos suyos (ocupa, en el panorama poético de sus tiempos, un lugar parecido al de fray Luis de León y Francisco de Aldana), pero muestran a la vez un marcado sello personal.

Creo que mi tesis deja resueltos todos los enigmas con que se han topado los críticos, y no creo haber dejado ningún cabo suelto de importancia. El siguiente paso sería, naturalmente, encontrar las huellas que debe de haber dejado Francisco de la Torre Escobar en los archivos colombianos. Reconozco que mi argumento central en pro de la bogotanidad de Torre es el más difícil de probar more philologico. La materia prima de este argumento es de índole abstracta: "rareza", "soledad", "marginalidad". Aquí deben entrar, naturalmente, las consideraciones sociopolíticas, pues la Nueva Granada en que vivió Torre, comparada con la Nueva España y el Perú de entonces, era a su vez una zona "marginal". (Francisco de Terrazas no es "raro" porque vive en México, respetable sucursal de la Poesía Española.) Pero también deben entrar las vivencias del solitario, esas rêveries que se reflejan en el cristal de sus versos; y deben entrar sus lecturas de poetas españoles - Garcilaso, fray Luis, Herrera y otros - y de poetas italianos, así como sus predilecciones léxicas y sintácticas y sus innovaciones métricas. Francisco de la Torre es tan "raro", a su manera, como lo será un siglo después otro bogotano, Francisco Álvarez de Velasco. Con diferencias: Torre leyó a muchos poetas y Álvarez de Velasco a 
pocos (no da señales de conocer a Lope ni a Góngora: su dios es Quevedo); y la expresión de su melancólica soledad está no sólo en sus versos (que ostentan, por cierto, no pocas "rarezas" métricas), sino también en sus abundantes confesiones autobiográficas. Por otra parte, en el transcurso de la actividad creadora de Torre no hubo un episodio tan preciso y tan trascendente como el descubrimiento de Sor Juana por Álvarez de Velasco ${ }^{72}$ - descubrimiento que lo hizo cambiar el rumbo, dejando a un lado el lóbrego ascetismo de sus larguísimos poemas sobre Muerte, Juicio e Infierno y sus versos a la Pasión de Cristo, a los Dolores de la Virgen y a "Nuestra Señora de la Tristeza", y le enseñó el arte de juguetear, sobre todo en los versos dirigidos a la propia Sor Juana, "paisanita querida":

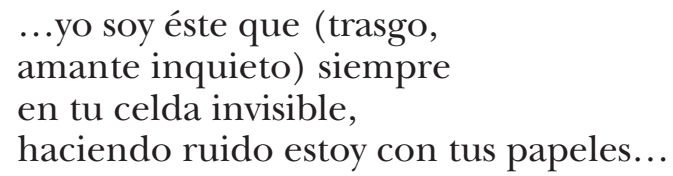

Pero la comparación entre los dos bogotanos tendría que ser objeto de un estudio aparte.

Antonio Alatorre

El Colegio de México

72 Cf. A. Alatorre, "Un devoto de Sor Juana: Francisco Álvarez de Velasco", Fil, 20 (1985), núm. 2, 157-176. 